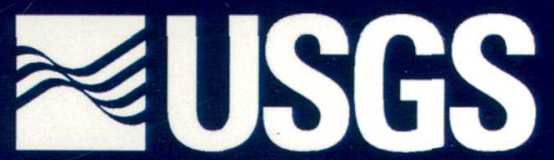

science for a changing world

In cooperation with the

City of Columbus, Ohio, Division of Water

\title{
Simulation of the Effects of Nearby Quarrying Operations on Ground-Water Flow at the South Well Field, Franklin County, Ohio
}

Water-Resources Investigations Report 99-4136

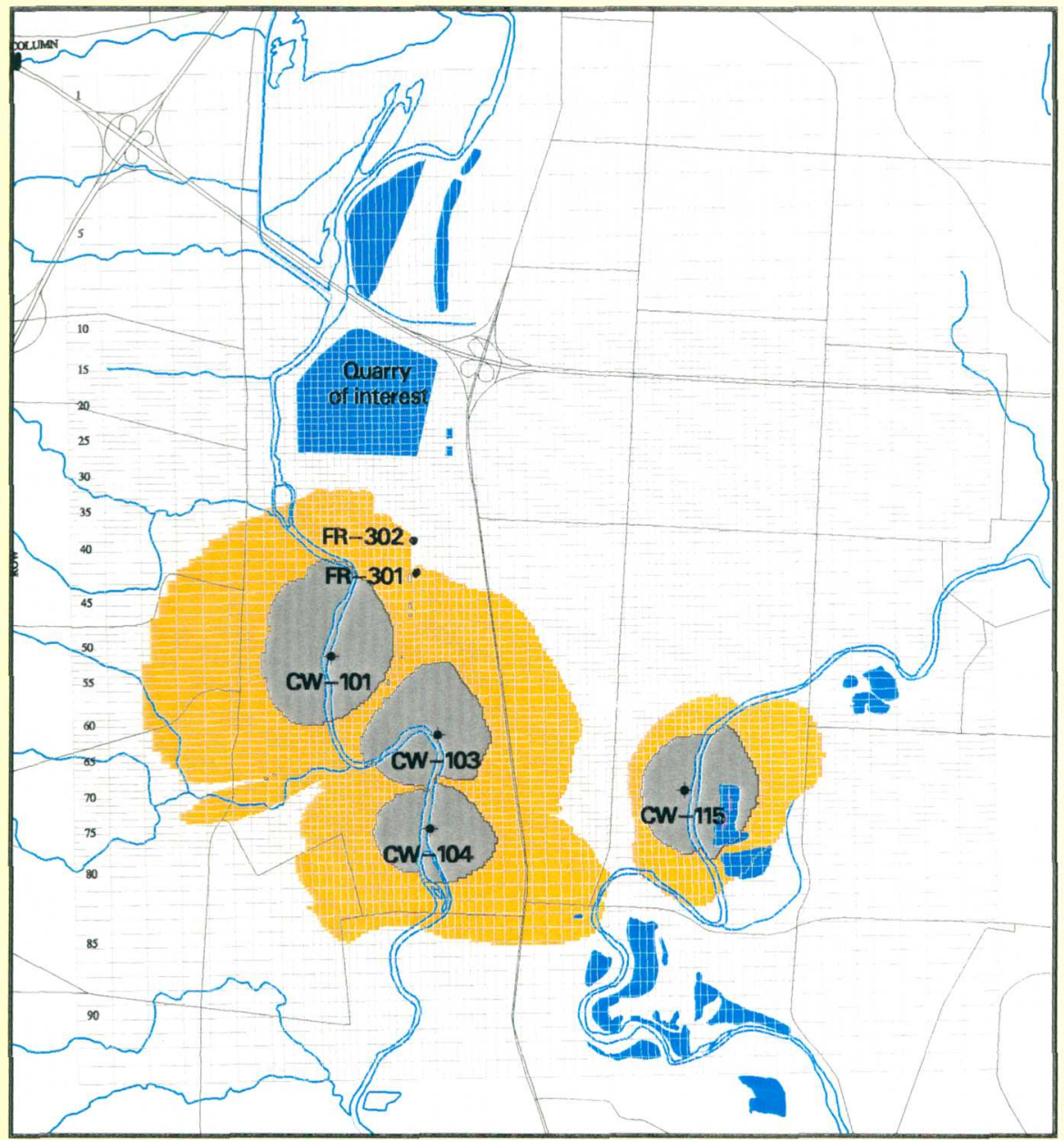


Cover: Diagram showing contributing recharge areas delineated in one of the ground-water flow simulations described in this report. (Entire illustration is figure 6 , on page 13.) 
U.S. Department of the Interior

U.S. Geological Survey

\section{Simulation of the Effects of Nearby Quarrying Operations on Ground-Water Flow at the South Well Field, Franklin County, Ohio}

By Gregory M. Nalley and Ralph J. Haefner

Water-Resources Investigations Report 99-4136 


\section{U.S. Department of the Interior \\ Bruce Babbitt, Secretary}

\section{U.S. Geological Survey}

Charles G. Groat, Director

Any use of trade, product, or firm names is for descriptive purposes only and does not imply endorsement by the U.S. Government.

For additional information write to:

District Chief

U.S. Geological Survey

6480 Doubletree Avenue

Columbus, $\mathrm{OH} 43229-1111$

Copies of this report can be purchased from:

U.S.Geological Survey

Branch of Information Survices

Box 25286

Denver, CO 80225-0286 


\section{CONTENTS}

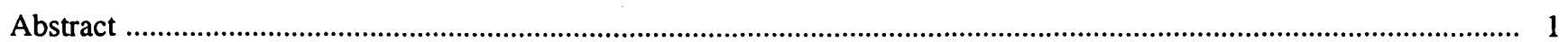

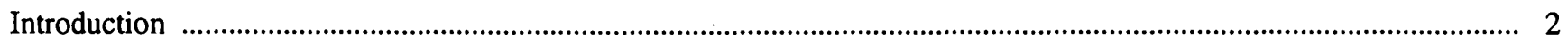

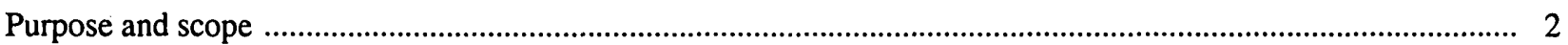

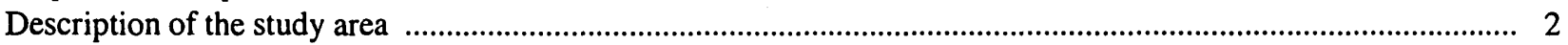

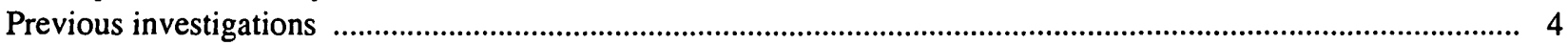

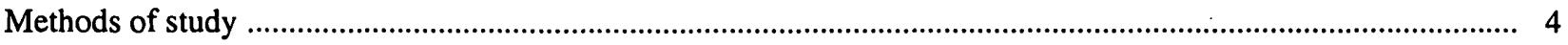

Simulation of the effects of quarrying operations on ground-water flow ................................................................... 4

Simulation 1 -Revised ground-water flow model ……...................................................................................... 5

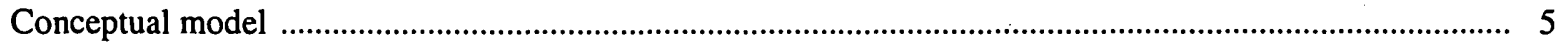

Assumptions for numerical model ................................................................................................................... 6

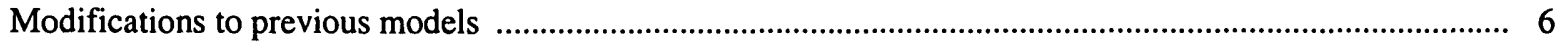

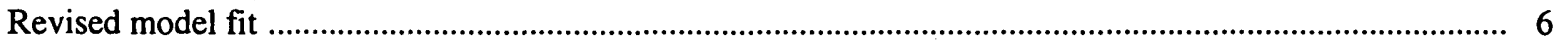

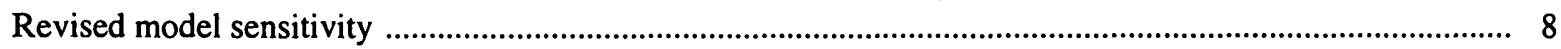

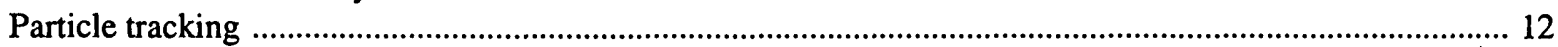

Simulation 2-Quarry with 20-foot layer of undisturbed aquifer material ............................................................. 12

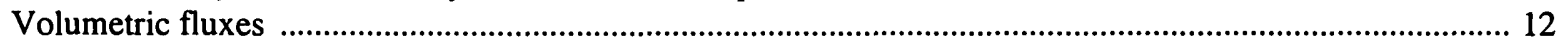

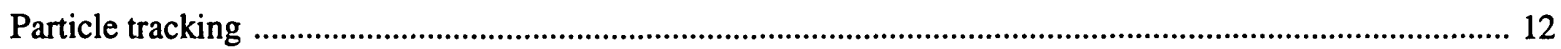

Simulation 3-Quarry with removal of 20-foot layer of undisturbed aquifer material .............................................. 15

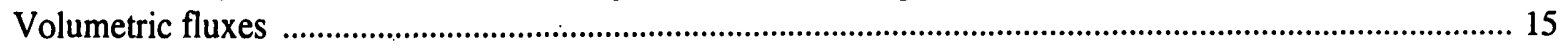

Particle tracking ……........................................................................................................................................ 15

Simulation 4 -Quarry filled with low-transmissivity aquifer material over 20 -foot layer

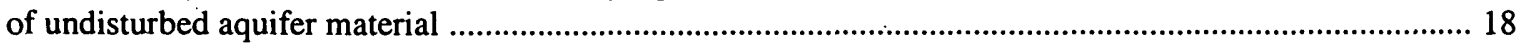

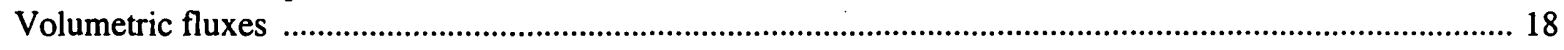

Particle tracking ............................................................................................................................................ 18

Simulation 5-Quarry filled with low-transmissivity aquifer material with the 20- foot layer of undisturbed aquifer material removed ....................................................................................................... 18

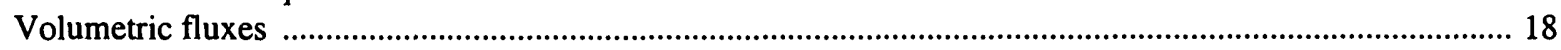

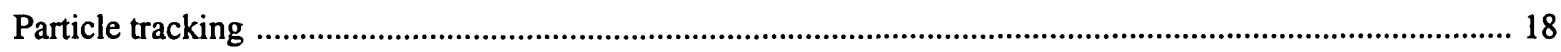

Simulated effects of quarrying operations on proportion of source waters for wells ............................................. 18

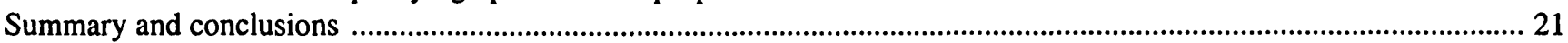

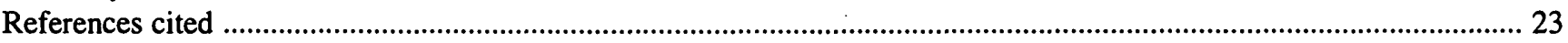

FIGURES

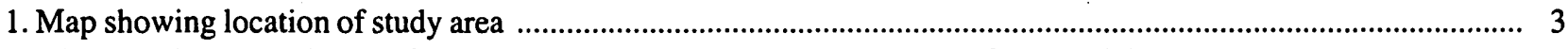

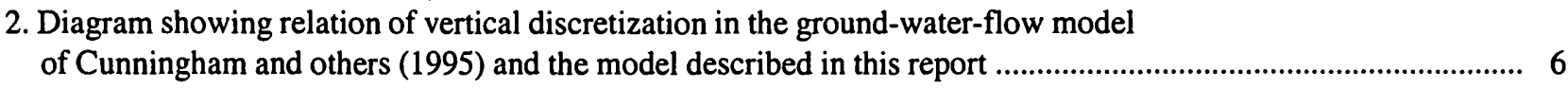

3. Map showing finite-difference grid of top layer of revised ground-water flow model ........................................... 7

4. Map showing simulated water-table configuration from the revised ground-water flow model ............................. 9

5. Graphs showing summary statistics of the response of the revised ground-water flow model

to changes in hydraulic conductivity of layers 1,2 , and 3; recharge; and riverbed conductance ............................. 11

6. Map showing contributing recharge areas for the revised ground-water flow model .............................................. 13

7. Graph showing selected volumetric fluxes for five ground-water flow simulations ................................................. 14 
8-11. Maps showing contributing recharge areas:

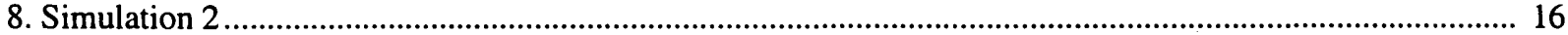

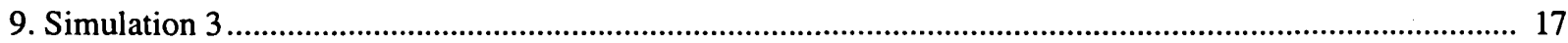

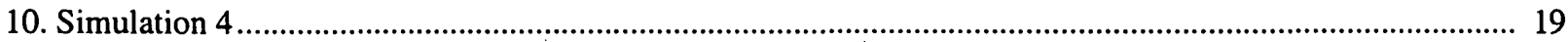

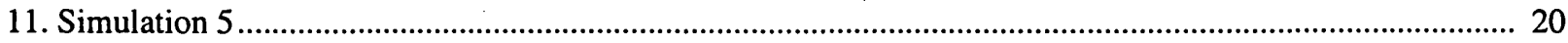

12. Graph showing proportions of source waters for pumped wells from five ground-water flow simulations ............ 22

\section{TABLES}

1. Comparison of volumetric fluxes from the ground-water flow model of Schalk (1996) and the revised model 10

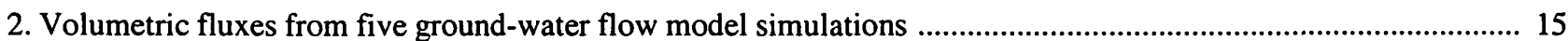

3. Percentage of water derived from different sources for five ground-water flow simulations .............................. 21

\section{CONVERSION FACTORS AND VERTICAL DATUM}

\begin{tabular}{rll}
\hline Multiply & By & To obtain \\
\hline foot $(\mathrm{ft})$ & Length & meter \\
cubic foot per second $\left(\mathrm{ft}^{3} / \mathrm{s}\right)$ & 0.3048 & cubic meter per second \\
cubic foot per day $\left(\mathrm{ft}^{3} / \mathrm{d}\right)$ & 0.02832 & cubic meter per day \\
million gallons per day & 0.02832 & cubic meter per second \\
\hline
\end{tabular}

Sea level: In this report, "sea level" refers to the National Geodetic Vertical Datum of 1929 (NGVD of 1929)-a geodetic datum derived from a general adjustment of the first-order level nets of both the United States and Canada, formerly called Sea Level Datum of 1929.

Transmissivity: The standard unit for transmissivity is cubic foot per day per square foot times foot of aquifer thickness $\left[\left(\mathrm{ft}^{3} / \mathrm{d}\right) / \mathrm{ft}^{2}\right] \mathrm{ft}$. In this report, the mathematically reduced form, foot squared per day $\left(\mathrm{ft}^{2} / \mathrm{d}\right)$, is used for convenience. 


\title{
Simulation of the Effects of Nearby Quarrying Operations on Ground-Water Flow at the South Well Field, Franklin County, Ohio
}

\author{
by Gregory M. Nalley and Ralph J. Haefner
}

\section{Abstract}

The City of Columbus, Ohio, operates a municipal well field in southern Franklin County that is adjacent to a sand and gravel mining operation. Mining operations have the potential to alter ground-water flowpaths and change the sources of water to pumped wells. Previous ground-waterflow modeling of the area has shown that water pumped from the supply wells is derived from infiltration from nearby rivers and surrounding bedrock. Some of that water flows through existing quarries. Because water quality differs among these sources and is affected by the path along which water flows to the wells, five flow conditions were simulated to evaluate the influence of different mining scenarios on sources of water as related to the size and shape of contributing recharge areas (CRA's) to wells. The first simulation was based on a revision of an existing model by Schalk (1996). The second and third simulations included one in which a 20-foot layer of undisturbed aquifer material within the quarry above the bedrock is left intact, and another in which the 20-foot layer is removed. The fourth and fifth simulations included one in which the 20-foot layer of undisturbed aquifer material is left above the bedrock and the quarry is backfilled with fine-grained sand and silt (a byproduct of the mining operations), and another in which the
20 -foot layer is removed before the quarry is backfilled with the fine-grained sand and silt.

The results of the five model simulations indicate that the overall volumetric budgets among models change only slightly in response to changing conditions at the quarry. The most significant change is noted in the amount of water that the aquifers gained from constant head and river leakage. This change is due to the way the quarries were simulated and lower heads in the aquifers compared to those in simulations made with earlier models. Previously published model simulations showed that the 5-year CRA's did not extend into the area of the newest sand and gravel quarry. In this study, however, the size and shape of the CRA's differ in response to the addition of two supply wells, and the 5-year CRA for one of these wells intersects the sand and gravel quarry.

Particle-tracking analysis indicates that the proportions of water from the principal water sources-rivers, other quarries (excluding the quarry of interest), and bedrock-stayed relatively constant among the model simulations. The number of particles that originate in the quarry of interest increased from about 1 percent of the total particles withdrawn through all wells when the 20-foot layer of undisturbed aquifer material was left intact, to 2 percent when the 20-foot layer was removed. In simulations in which the quarry of interest was filled with fine-grained sand and silt, the percentage of particles that travel through or 
originate in that quarry decreased to less than 1 percent of the total number of particles. Thus, the mining activities at the quarry of interest, combined with increased pumping at the two supply wells, have only a small potential to change the overall quality of water withdrawn from supply wells at the South Well Field.

\section{Introduction}

The City of Columbus, Ohio, operates the South Well Field, a municipal well field consisting of four Ranney radial collector wells and two conventional supply wells in southern Franklin County. The South Well Field is adjacent to a sand and gravel mining operation (hereafter referred to as the quarry of interest). The mining company is removing sand and gravel deposits by use of dredging techniques and replacing them with fine-grained sand and silt that result from the washing process. Mining of the sand and gravel has the potential to cause an increase in the amount of water contributed from the underlying limestone bedrock aquifer to the municipal supply wells. This change in proportions of source water to the supply wells may cause the cost of water treatment to increase because the water in the bedrock is of lesser quality (commonly has elevated concentrations of hydrogen sulfide and hardness) than water found within the sand and gravel aquifer. The City and the mining company have reached a verbal agreement whereby $20 \mathrm{ft}$ of undisturbed aquifer material will remain on top of the bedrock to reduce the potential for mixing of water from the bedrock with water from the sand and gravel aquifer in the quarried area. The hydrogeologic effect of quarrying activities and of the 20 - $\mathrm{ft}$ layer of undisturbed aquifer material has not been identified and characterized. The U.S. Geological Survey (USGS), in cooperation with the City of Columbus, has developed a conceptual model of flow and constructed a steady-state ground-water flow model to simulate different mining scenarios in the area. This investigation builds on a large body of prior cooperative efforts between the USGS and the City of Columbus to characterize hydrogeology and water quality in southern Franklin County.

\section{Purpose and scope}

This report documents a study of the effects of proposed sand and gravel mining on the hydrology of the South Well Field and describes ground-water-flow paths in relation to current and near-future quarrying operations. Long-term quarrying operations are not covered in this report. Simulation of ground-waterflow in the South Well Field area is limited to the analysis of the shallow flow system in the sand and gravel aquifer and the limestone bedrock aquifer.

\section{Description of the study area}

The South Well Field, hereafter referred to as the "the study area," lies along the Scioto River and is north of the confluence of the Scioto River and Big Walnut Creek in southern Franklin County (fig. 1). Only a brief summary of the hydrogeology of the study area is given here because this area has been extensively described by de Roche and Razem (1984), de Roche (1985), Eberts and Bair (1990), Cunningham and others (1995), and Schalk (1996).

The study area is underlain by a glacially incised valley that is filled with sand and gravel outwash deposited during the Illinoian and Wisconsinan glaciations. The sand and gravel deposits are lenticular and include discontinuous clay layers that locally may confine underlying aquifers. Glacial outwash is as thick as $200 \mathrm{ft}$ in some places within the study area. The underlying bedrock consists of Devonian Columbus Limestone to the west and the Ohio Shale to the east, with the contact lying roughly parallel and adjacent to the Scioto River.

Ground-water flow in the area is toward the Scioto River and to the south. Ground-water levels are generally less than 20 to $25 \mathrm{ft}$ below land surface and fluctuate annually in response to seasonal recharge variations, stage in the Scioto River and Big Walnut Creek, and ground-water pumping. A limestone quarry to the north of the study area has extensive dewatering operations that create a ground-water divide between the collector wells and the limestone quarry.

As of 1999, six wells within the South Well Field withdraw a total of approximately $24.7 \mathrm{Mgal} / \mathrm{d}$. Four radial collector wells withdraw approximately 22.7 Mgal/d. These wells are adjacent to the Scioto River and Big Walnut Creek (fig. 1) and were 

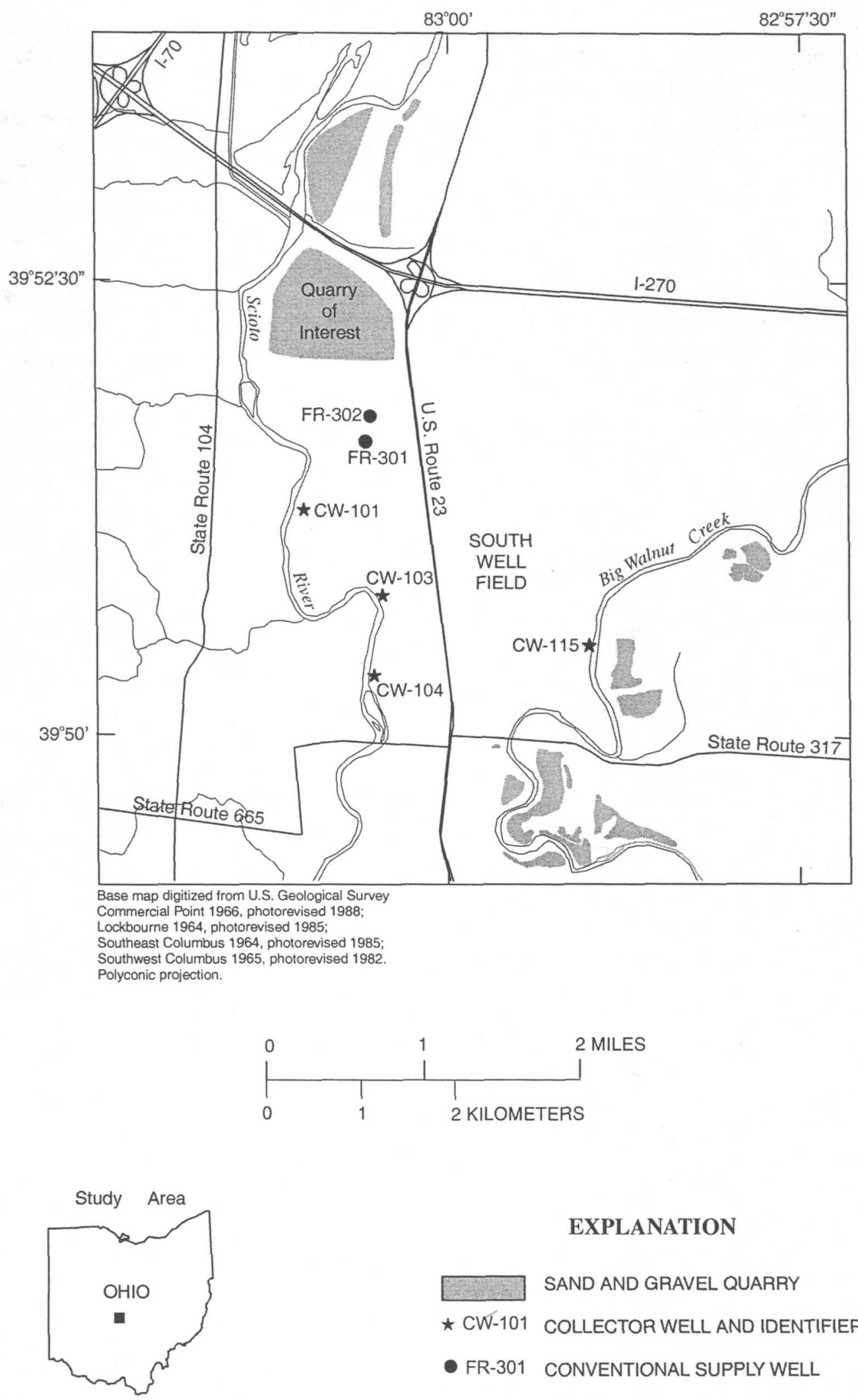

\section{EXPLANATION}

SAND AND GRAVEL QUARRY

^ CW-101 COLLECTOR WELL AND IDENTIFIER

- FR-301 CONVENTIONAL SUPPLY WELL

Figure 1. Location of study area (modified from Schalk, 1996). 
designed to induce infiltration from these streams. The two conventional supply wells wells (FR-301 and FR-302) withdraw approximately $1 \mathrm{Mgal} / \mathrm{d}$ each; they were not active during previous study periods, but they are now active and included in this analysis.

Land use in the area has been primarily agricultural, with row crops such as corn and soybeans being produced. As previously mentioned, some of this land is now being mined for sand and gravel by use of dredging techniques. The sand and gravel is washed with water to remove fine-grained sand and silt, which are deposited in an adjacent settling pond. Where the highly transmissive sand and gravel deposits have been mined out, they are being replaced with material of lower hydraulic conductivity composed of finegrained sand and silt.

The mining company has obtained rights to mine the materials that comprise the principal aquifer in the study area from which the City of Columbus withdraws water. Currently, mining operations are not within the 5-year contributing recharge area (CRA) as simulated by Schalk (1996, fig. 9, p. 15). Future mining plans, however, include continued movement of mining operations to the south, adjacent to the collector wells, and mining of limestone bedrock.

\section{Previous investigations}

Previous ground-water flow modeling efforts have focused on several different aspects of the groundwater flow system. Bair and others (1990) estimated traveltimes of contaminants along ground-water flowpaths to selected wells in the event of a spill near major transportation corridors. Because induced infiltration from rivers is a major source of water to pumped wells, Cunningham and others (1995) quantified the contribution of water from surface-water infiltration by use of a ground-water flow model and seepage-meter measurements within selected reaches of the Scioto River. Schalk (1996) defined 1-, 5-, and 10-year traveltimerelated CRA's for the four collector wells within the South Well Field. These studies accounted for quarrying and dewatering operations to the north of I-270 (fig. 1) and to the southeast of the collector wells. However, they did not include the recent mining operations at the quarry of interest near the radial collector wells and conventional supply wells.

\section{Methods of study}

The ground-water flow simulations presented in this report are based on steady-state models by Cunningham and others (1995) and Schalk (1996). The difference between this study and previous studies is that the model used in the current study (also referred to as the revised model) was modified from earlier versions by splitting the middle layer into two layers, thereby adding a model layer to simulate the 20 -ft-thick layer of undisturbed aquifer material. The grid spacing of the model used here is more finely discretized than that of earlier models, and an additional column has been added along the western boundary. After these revisions, the model output was compared to output from the two previous models to ensure that the revisions did not unexpectedly alter the behavior or the output of the model. Additional input data included in this model are limited to increased pumping rates from the collector wells, inclusion of the two conventional supply wells, and simulation of the quarry of interest.

Pumping rates of the four collector wells and the two conventional supply wells were supplied by the City of Columbus. The location and extent of the quarry of interest was estimated from 1:24,000-scale topographic maps, site visits, and aerial photography supplied by the City of Columbus. All other input data used in this model were either obtained from steadystate models by Cunningham and others (1995) and Schalk (1996) or recalculated from those studies on the basis of new model-cell dimensions.

\section{Simulation of the effects of quarrying operations on ground-water flow}

To simulate the ground-water flow scenarios in relation to the mining operations in the study area, five model simulations were done. The description of these simulations are as follows:

Simulation 1-The revised model was fitted to the results of the steady-state models by Cunningham and others (1995) and Schalk (1996).

Simulation 2-The quarry of interest and all other sand and gravel quarries, excluding the dewatered limestone quarry north of the study area, were simulated as open water by use of zones of high transmissivity and high porosity. Within the quarry of interest, a 20 - $\mathrm{ft}$ layer of undisturbed aquifer material (layer 3) was left intact.

Simulation 3-The 20-ft layer of undisturbed aquifer material was removed from the quarry of inter- 
est and replaced with a zone of high transmissivity and high porosity to simulate open water.

Simulation 4-Layers 1 and 2 within the quarry of interest were backfilled with fine-grained sand and silt and were represented by zones of low hydraulic conductivity.

Simulation 5-Layers 1, 2, and 3 within the quarry of interest were filled with fine-grained sand and silt and were represented by zones of low hydraulic conductivity.

Simulation 1 was intended to mimic the steadystate simulation of Schalk's (1996) predictive simulation. Schalk's model was calibrated to pumping rates of $8 \mathrm{Mgal} / \mathrm{d}$, and pumping rates were increased to $22 \mathrm{Mgal} / \mathrm{d}$. Simulations 2 through 5 are predictive simulations; therefore, adjustment to fit observed conditions beyond simulation 1 (the revised model) and the simulation of Schalk (1996) was not possible. Because the revised model presented in this report duplicated the heads and flows of Schalk's (1996) predictive simulation, the subsequent model simulations were assumed to represent the ground-water flow system in an acceptable and realistic way.

The only changes in simulations 2 through 5 are those related to activities that may be related to quarrying. Quarries in the model simulations prepared by Cunningham and others (1995) and Schalk (1996) were simulated as general head boundaries with a fixed head value equal to the average water level in the quarry. For simulations 2 through 5 , quarries were simulated by replacing the general-head boundaries with an area of high hydraulic conductivity and (or) transmissivity. Hydraulic conductivity in layer 1 in the vicinity of the quarry of interest in Schalk's model (1996) ranged from 50 to $375 \mathrm{ft} / \mathrm{d}$, whereas hydraulic conductivity in the revised model simulations was increased by 2 orders of magnitude for every cell within the quarry, to values of 5,000 to $37,500 \mathrm{ft} / \mathrm{d}$. A porosity of 100 percent was assigned to all quarry grid cells for computation of particle traveltimes in the program MODPATH (Pollock, 1994). The quarry of interest was not simulated by Cunningham and others (1995) or Schalk (1996) but was included in the revised model simulations by replacing 242 grid cells north of the collector wells with a high-transmissivity zone.

Close examination of the configuration of the computed CRA's for all five models shows that, between each model run, the boundaries may shift by one or two cells. Even when the only changes in the model are made near the quarry of interest, there may still be small changes in the configuration of the computed 5-year CRA's several miles from the area of model modifications. This edge actually lies within a zone of uncertainty. Therefore, if the edge of a CRA needs to be delineated, a thick, dashed line (at least one half the width of the grid cell) would be more appropriate.

\section{Simulation 1-Revised ground-water flow model}

Ground-water flow modeling and particle-tracking analyses in this study were done with MODFLOW (McDonald and Harbaugh, 1988) and MODPATH (Pollock, 1994), respectively. MODFLOW is a threedimensional, finite-difference, numerical computer program that uses hydrogeologic input data in discrete cells to simulate ground-water flow. MODPATH uses output data from MODFLOW to track hypothetical particles of water through the ground-water flow system. By tracking particles of water "released" at the water table to a pumped well, an approximate CRA for the well can be delineated for a given time period.

Conceptual model. A conceptual model of ground-water flow was devised during the early stages of this project and was based on the conceptualization given in Schalk (1996). The major difference between Schalk's model (1996) and the revised model presented in this report is the manner in which quarries are simulated. Cunningham and others (1995) and Schalk (1996) simulated quarries by use of a general head boundary, whereas the revised model used in this study simulates the quarries by use of high transmissivity value and a porosity of 100 percent. This change was made to provide a more realistic representation of the quarries in the model and to facilitate particle tracking within the quarries.

The type of external boundaries of the model area are identical to those described in Cunningham and others (1995) and Schalk (1996). The northern and southern boundaries are no-flow boundaries, whereas the eastern and western boundaries are specified-flux boundaries simulated with recharging wells. The upper boundary represents the water table, whereas the lower boundary represents a no-flow boundary.

Internal boundaries include surfaçe-water bodies and quarries. The surface-water bodies, which include the Scioto River and Big Walnut Creek, are important hydrologic features in the model because of the contribution of water by induced infiltration. 
Values of stage, river area, and streambed conductance vary throughout the study area and are estimated from Cunningham and others (1995).

Sources of water to the model area include precipitation (recharge) on the uppermost active layer and regional ground-water inflow from the east and west. Sinks of water include pumping at the radial collector wells and the conventional supply wells, ground-water discharge into rivers, and dewatering at a limestone quarry to the north of the study area. Water removed from the ground-water system by dewatering at the limestone quarry is pumped into the Scioto River.

Assumptions for numerical model. The assumptions for this steady-state model are identical to those reported in Schalk (1996) and Cunningham and others (1995). Model assumptions include aquifer isotropy and homogeneity within each model grid cell, and a steady-state hydrologic system. Additionally, model boundaries are assumed to be far enough away from the area of interest so as to minimize any effects on the simulation results.

\section{Modifications to previous models. An} examination of the effects of quarrying operations in the study area indicated the need to modify the ground-water flow models by Cunningham and others (1995) and Schalk (1996) for the purposes of the current study. First, the horizontal discretization was refined to better define the potentiometric surface and ground-water flowpaths near the wells and the quarry. The length and width of grid cells in the revised model range from 200 to $1,000 \mathrm{ft}$. Second, a single model column in all four layers was added along the western boundary of the model because simulations by Schalk (1996) showed that the CRA's for collector wells CW-101 and CW-103 reached this boundary. Third, an additional model layer was added. The model by Cunningham and others (1995) contained three layers. Layer 3 represented limestone bedrock, layer 2 represented the screened interval of the supply wells within glacial outwash, and layer 1 represented the overlying glacial outwash. Layer 2 in the previous models was split into layers 2 and 3 in the revised model to investigate the significance of the 20 -ft layer of undisturbed aquifer material, represented by the new layer 3

(fig. 2), as well as to facilitate inclusion and removal of this layer in model simulations. Finally, the discretization of river cells was revised because the finer discretization of the model grid resulted in many river cells that did not contain a river.

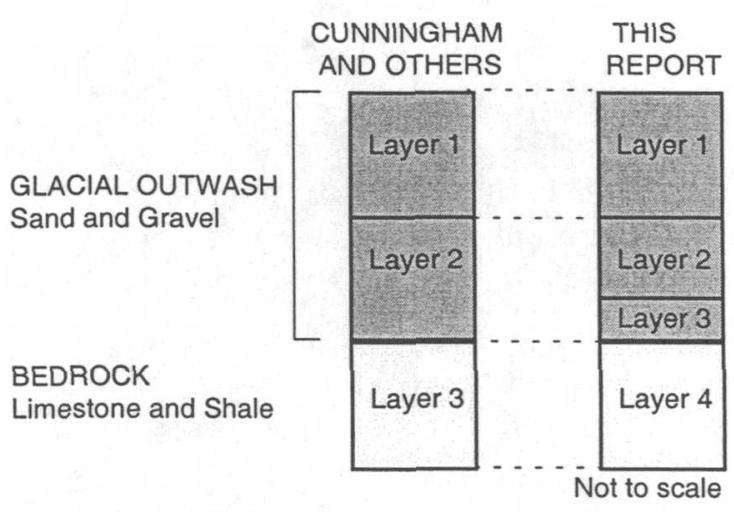

Figure 2. Relation of vertical discretization in the ground-water-flow model of Cunningham and others (1995) and the model described in this report.

The previous finite-difference grid consisted of 53 rows, 45 columns, and 3 layers with 7,155 active grid cells. The revised model has 94 rows, 74 columns, and 4 layers with 27,824 active grid cells (fig. 3).

Hydraulic characteristics of each grid cell were retained in the new model where applicable. Several hydraulic parameters including transmissivity, vertical conductance, and riverbed conductance, are based on cell dimensions and were recalculated whenever the dimensions of the cells were changed.

Hydraulic characteristics of each model layer from Cunningham and others (1995) were copied to the corresponding layer in the new model. Layer 1 was not changed. Hydraulic characteristics of layer 2 in that model were propagated into layers 2 and 3 in the revised model. No changes were made to layer 3 in the model by Cunningham and others, but it is designated layer 4 in the revised model.

Revised model fit. Revisions to Cunningham and others' model (1995) were initiated with inclusion of the additional model layer and use of the finer and more aerially extensive model grid. Theoretically, these revisions should not greatly affect the overall distribution of simulated head and flows. The revised model described in this report was fitted to simulated heads and flows from models presented in Schalk (1996), which were calibrated with lower pumping rates to measured heads and flows in the field. Cunningham and others (1995) simulated conditions in the study area with pumping from the collector wells set at $8.4 \mathrm{Mgal} / \mathrm{d}$. Schalk (1996) included predictive model simulations for pumping up to $22 \mathrm{Mgal} / \mathrm{d}$. Current (1999) conditions include pumping 


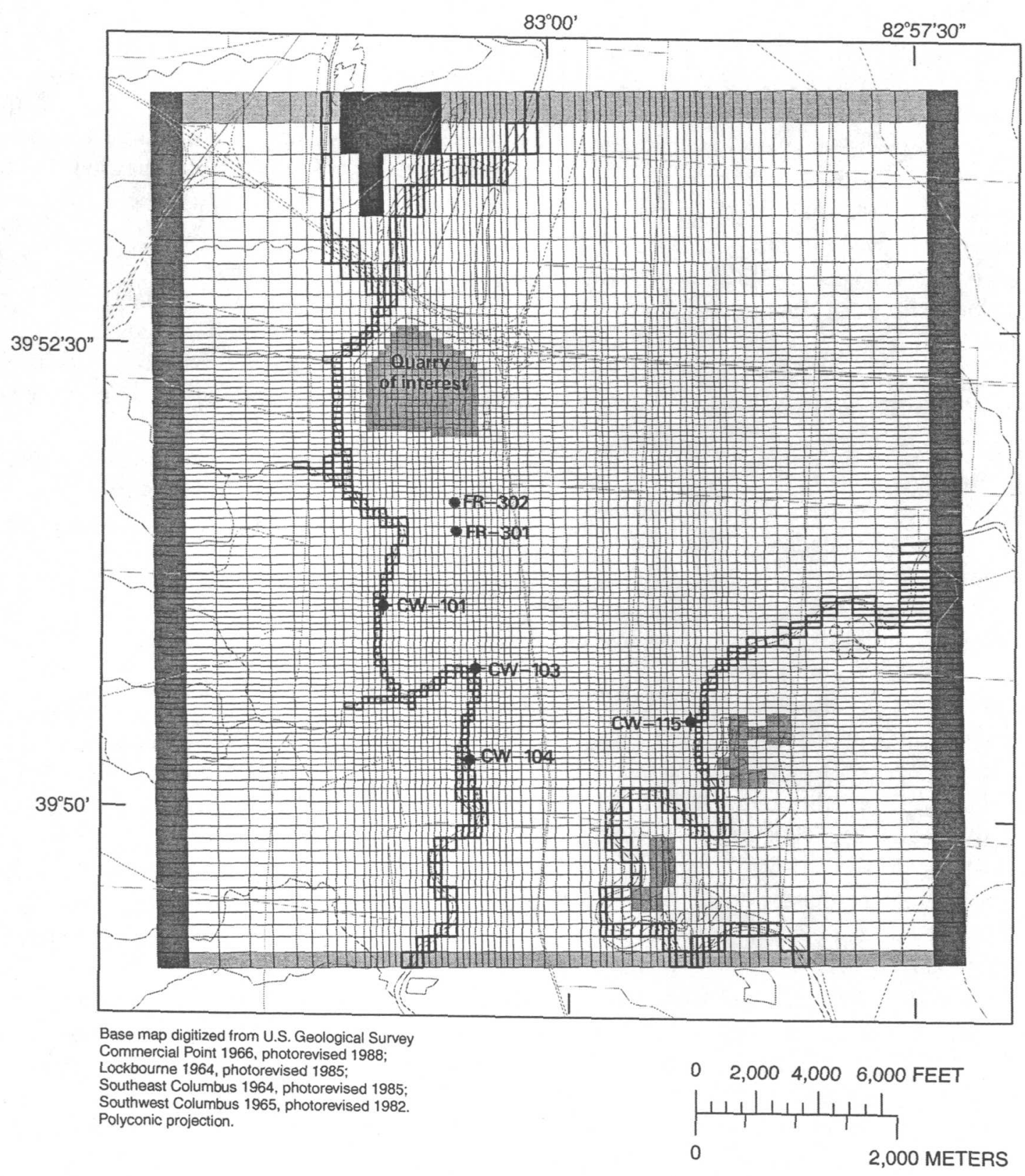

\section{EXPLANATION}

SPECIFIED FLUX ROAD

NO FLOW

C RIVERS AND QUARRIES

CONSTANT HEAD

QUARRY

- radial collector well

- vertical well

RIVER CELL

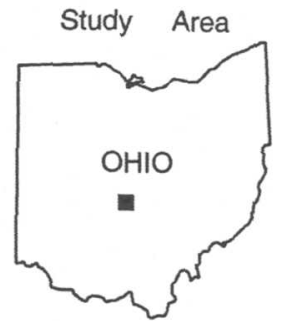

Figure 3. Finite-difference grid of top layer of revised ground-water flow model in southern Franklin

County, Ohio (modified from Cunningham and others, 1995). 
at $22.7 \mathrm{Mgal} / \mathrm{d}$; thus, the revised model was fitted to match the predictive output of Schalk's model (1996).

After these initial modifications, simulations were done to see whether heads and flows were reasonably close to those of Schalk (1996). The only other modifications required for model matching to Schalk (1996) were to calculate the vertical conductance between layers 2 and 3 and to recalculate the vertical conductance between layers 1 and 2 and between layers 3 and 4 . To achieve the best model fit, vertical conductance between layers 1 and 2 was reduced by 1 order of magnitude and vertical conductance between layers 3 and 4 was increased by a factor of 4 from the values used in Schalk (1996).

The head distribution in layer 1 , represented by a contour map of the water table, is shown in figure 4 . This map closely resembles the head distribution resulting from Schalk's simulation (1996). Overall, the potentiometric surface is slightly lower than that of Schalk (1996). Differences in water-table elevation are significant along the northern boundary of the model area, where heads simulated in the revised model are several feet lower than those simulated by Schalk (1996). Possible explanations for these differences may include decreased river leakage (due to the decreased area of the riverbed resulting from rediscretization of the river cells) and adjustments in vertical conductance. Although riverbed conductance values were adjusted according to the revised grid cell dimensions, the decreased number of river cells that could gain or lose water results in a decrease in the area available to exchange water with the aquifer. On the whole, these differences are of minor consequence with regard to the utility of the revised model. Of greatest importance to subsequent model simulations is that the water-table configuration near the radial collector wells and quarry of interest is almost identical to that simulated by Schalk (1996).

Volumetric fluxes from Schalk's model (1996) and the revised model are listed in table 1. Most of the quantities of water derived from sources or sinks differ from to those of Schalk (1996) by less than 2 percent of the total flux, a match that was deemed acceptable for the purposes of this modeling study. The largest difference in flux is in the amount of water derived from the head-dependent flux boundaries, which include the sand and gravel quarries. Because heads throughout the modeled area are slightly lower in this model than for Schalk's model (1996), less water flows into the quarries, probably because of a decreased gradient between the aquifer and the quarries. The second largest difference in flux was from river leakage. Increases in river leakage were likely due to lower heads in layer 1 , which increased the gradient between the stage of the river and the aquifer. The amount of recharge increased by 0.50 percent between the two models. This increase was due solely to the addition of a grid column along the western boundary of the model.

After the revised model was fitted to Schalk's predictive model output (1996) and proven to function virtually the same as Schalk's predictive model (as shown in table 1), predictions based on this revised model were deemed suitable for the purposes of this study.

Systematic revisions were made so that the model would conform to current (1999) conditions. These revisions included increased pumping rates from the collector wells, inclusion of two conventional supply wells, and simulation of the quarry of interest.

\section{Revised model sensitivity}

The model of Cunningham and others (1995) was most sensitive to changes in riverbed conductance and increases in hydraulic conductivity. The model was shown to be relatively insensitive to changes in recharge. The sensitivity of the model to additional parameters was evaluated by Schalk (1996); however, sensitivity was assessed only with respect to changes in the size of CRA's. Additional model parameters identified by Schalk (1996) that influence the size of the CRA's were not evaluated.

Model sensitivity was assessed by computation of the mean absolute difference (MAD) between head values at all cells in the revised model as compared to the respective head values in all cells in the Schalk model (1996). MAD is defined as

$$
\mathrm{MAD}=\frac{\Sigma\left|h_{o}-h_{s}\right|}{n},
$$

where $h_{o}$ is the observed head in a given cell in Schalk's model (1996), $h_{s}$ is the simulated head in the corresponding grid cell for the revised model, and $n$ is the number of comparisons made. Because the horizontal and vertical discretization of these two models were different, a computer algorithm was written (R.A. Sheets, U.S. Geological Survey, 1998) to compare the head value $\left(h_{o}\right)$ in each cell in the Schalk model (1996) to the head value $\left(h_{s}\right)$ in the corresponding those in Schalk's layer 2. 


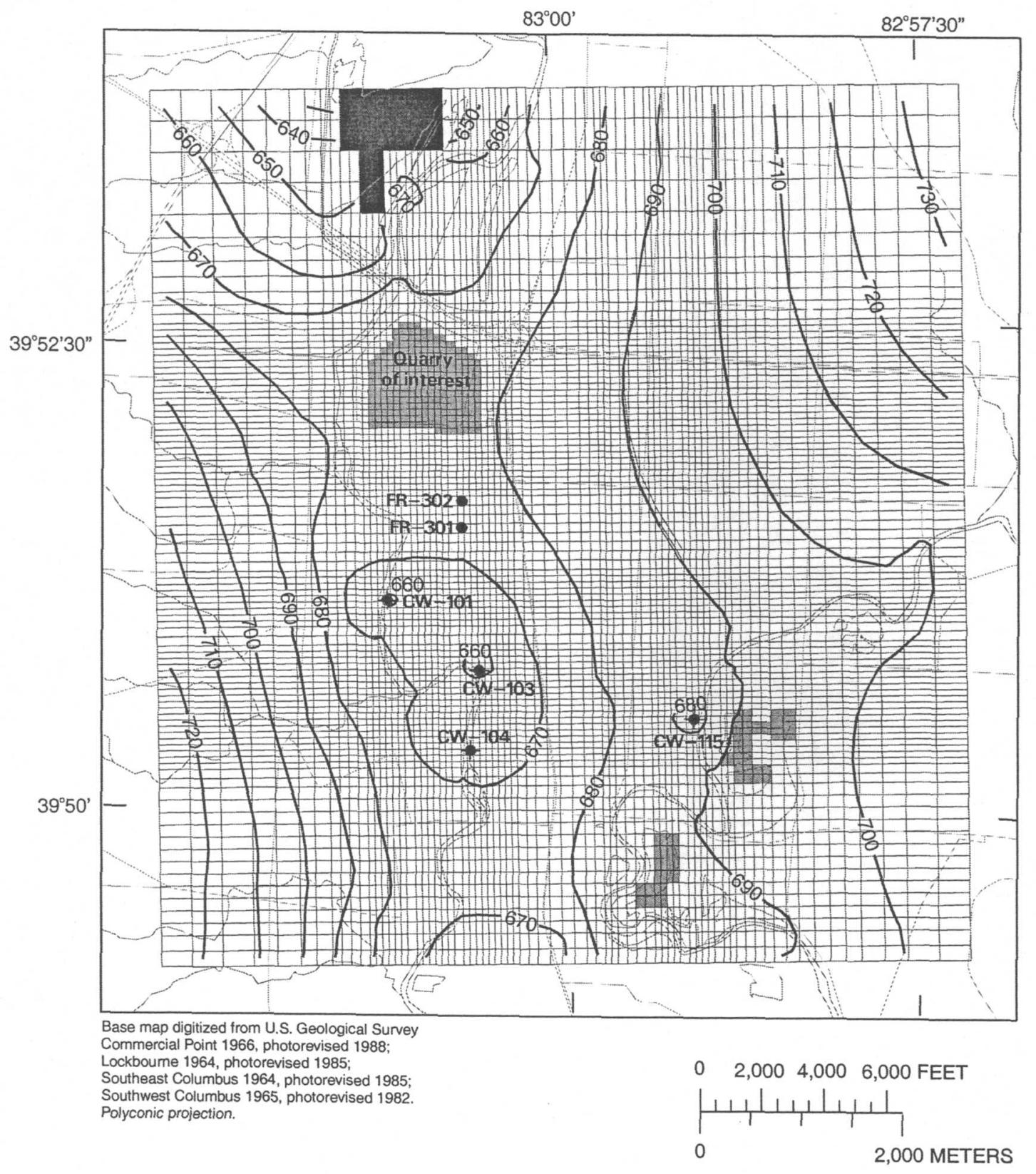

EXPLANATION

$\begin{array}{lll}\text { CONSTANT HEAD } & \text { ROAD } \\ \text { QUARRY } & & \text { RIVERS AND QUARRIES } \\ \begin{array}{l}\text { WATER-TABLE CONTOUR-- } \\ \text { in feet above sea level. } \\ \text { Contour interval 10 feet }\end{array} & -\quad \text { RADIAL COLLECTOR WELL } \\ & - & \text { VERTICAL WELL }\end{array}$

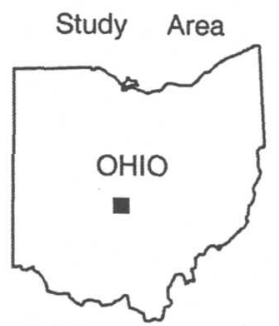

Figure 4. Simulated water-table configuration from the revised ground-water flow model, southern Franklin County, Ohio. 
Table 1. Comparison of volumetric fluxes from the ground-water flow model of Schalk (1996) and the revised model, southern Franklin County, Ohio

$\left[\mathrm{ft}^{3} / \mathrm{d}\right.$, cubic feet per day; IN, volume of water exchanged from source or sink into the aquifer; OUT, volume of water exchanged from source or sink out of the aquifer]

\begin{tabular}{|c|c|c|c|c|c|c|c|c|}
\hline \multirow{3}{*}{$\begin{array}{c}\text { Source or } \\
\text { sink of water }\end{array}$} & \multirow{2}{*}{\multicolumn{2}{|c|}{$\begin{array}{c}\text { Schalk's model } \\
\left(\mathrm{ft}^{3} / \mathrm{d}\right)\end{array}$}} & \multirow{2}{*}{\multicolumn{2}{|c|}{$\begin{array}{c}\text { Revised model } \\
\qquad\left(\mathrm{ft}^{3} / \mathrm{d}\right)\end{array}$}} & \multicolumn{4}{|c|}{ Difference between models } \\
\hline & & & & & \multicolumn{2}{|c|}{$\begin{array}{c}\text { As flow rate } \\
\left(\mathrm{ft}^{\mathbf{3}} / \mathrm{d}\right)\end{array}$} & \multicolumn{2}{|c|}{$\begin{array}{l}\text { As percent of } \\
\text { total flux }\end{array}$} \\
\hline & IN & OUT & IN & OUT & IN & OUT & IN & OUT \\
\hline Constant head & 0 & $2,690,100$ & 9,159 & $2,695,000$ & 9,159 & 4,900 & 0.14 & 0.07 \\
\hline Wells & $2,192,000$ & $3,043,000$ & $2,192,100$ & $3,043,000$ & 100 & 0 & 0.00 & 0 \\
\hline Drains & $\mathbf{0}$ & 8,289 & 0 & 6,388 & 0 & $-1,901$ & 0 & -0.03 \\
\hline Recharge & $1,467,200$ & 0 & $1,500,200$ & 0 & 33,000 & $\mathbf{0}$ & 0.50 & 0 \\
\hline River leakage & $2,297,800$ & 465,620 & $2,320,300$ & 435,730 & 22,500 & $-29,890$ & 0.34 & -0.46 \\
\hline Head-dependent boundary & 602,890 & 353,150 & 513,710 & 400,780 & $-89,180$ & 47,630 & -1.36 & 0.73 \\
\hline Total & $6,559,890$ & $6,560,159$ & $6,535,469$ & $6,580,898$ & $-24,421$ & 20,739 & & । \\
\hline
\end{tabular}

Traditional sensitivity analyses, such as those done by Cunningham and others (1995), compare simulated heads and flows to those measured at the field site. The following sensitivity analysis differs from traditional sensitivity analysis in two significant ways that may affect interpretation of the sensitivity of the model. First, even with a large number of observation wells available for fitting, matching targets are usually not obtained for each model grid cell. For the sensitivity analysis presented in this report, head comparisons are made with Schalk's model (1996) at every cell in each layer throughout the entire model area and not only those where water-level measurements are available. Second, the revised model can simulate groundwater flow at the study area only to the extent of the previous models. The input parameters used were taken or recomputed from Cunningham and others (1995), with revisions from Schalk (1996); improvements were not attempted as part of this study. Therefore, a best fit of the revised model to Schalk's model (1996) may not necessarily be shown by minimal values of MAD.

Results of the sensitivity analysis are shown for all four layers in figure 5. MAD for the steady-state model of Cunningham and others (1995) was about $4.1 \mathrm{ft}$ for all cells for which observation-well data were available. The mean of MAD values for all four layers of the revised model was about $1.9 \mathrm{ft}$. MAD in layer 1 was $1.6 \mathrm{ft}$, whereas MAD in layer 4 was about $2.4 \mathrm{ft}$.
The graphs in figure 5 show that the revised model may not necessarily reflect the lowest value of MAD for different values of input parameters. However, because the intent of this study was to use an existing model for the South Well Field and make predictions on the basis of several mining scenarios, the results were considered acceptable. By modifying the existing model and fitting the output to the predictive Schalk model (1996), the authors have ensured the revised model functions virtually the same as the predictive Schalk model (1996).

Changes in MAD were affected by both increases and decreases in hydraulic conductivity of the upper three layers. The sensitivity of the model to decreases in hydraulic conductivity is similar to that of Cunningham and others (1995). Their model, however, was found to be insensitive to increases in hydraulic conductivity of layers 1 and 2. Cunningham and others (1995) found their model to be insensitive to changes in recharge, whereas the revised model is sensitive to decreases and only slightly sensitive to increases. Decreases in riverbed conductance caused numerous cells in the revised model to go dry and MAD values for layers 2, 3, and 4 exceed to $30 \mathrm{ft}$, yet the model was relatively insensitive to increases in riverbed conductance.

These results indicate that, given the way MADwas computed, the revised model responds differently to changes in sensitive parameters as compared to the 


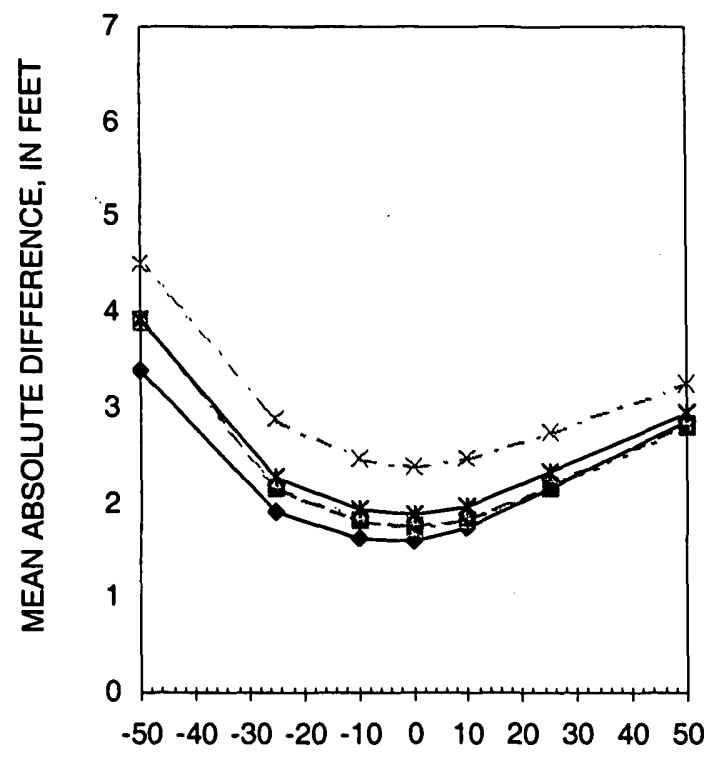

PERCENT CHANGE IN HYDRAULIC CONDUCTIVTY, LAYERS 1, 2, AND 3

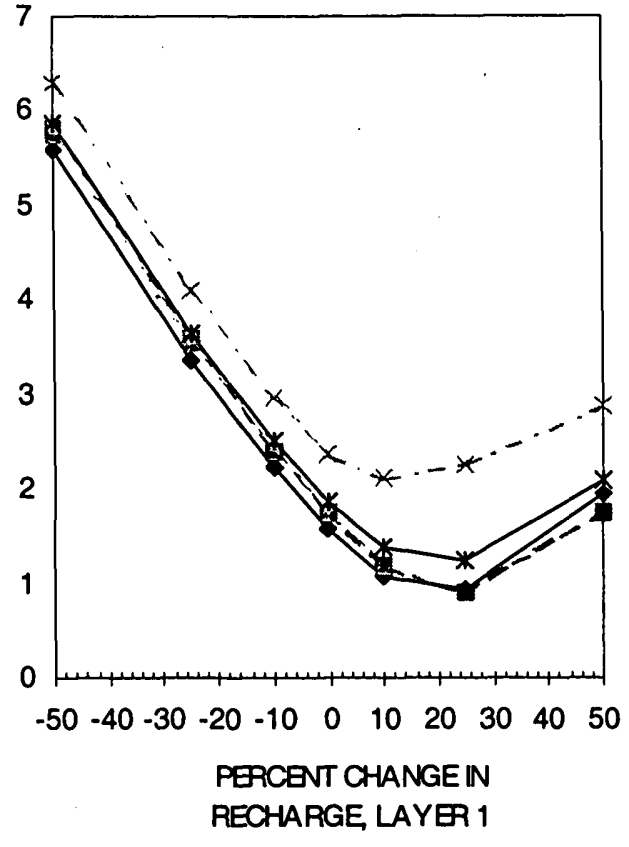

EXPLANATION

$\longrightarrow$ LAYER1

$-\rightarrow-$ LAYER 2

....... LAYER 3

$-\cdot * \cdot-$ LAYER 4

Figure 5. Summary statistics of the response of the revised ground-water flow model, southern Franklin County, Ohio, to changes in hydraulic conductivity of layers 1,2, and 3; recharge; and riverbed conductance. 
Cunningham and others model (1995). Cunningham and others (1995) concluded that their model was most sensitive to changes in riverbed conductance. The revised model behaves similarly in that small changes in riverbed conductance cause dramatic changes in the simulated heads and flows in the model. Probable reasons for differences between the revised model and the model by Cunningham and others (1995) include the decreased area covered by river cells, the differences in vertical conductance, and changes in pumping rates, which may cause a change in the source of water to pumped wells.

Particle tracking. Particle-tracking analysis by use of MODPATH (Pollock, 1994) was used to calculate CRA's for all pumping wells. This was done by placing 16 particles in a 4 by 4 horizontal array in each grid cell in layer 1 at the water table. These particles were simultaneously released and tracked to their discharge point (a pumped well, a river, downstream flow out of the model, or a constant-head cell). Particletracking endpoints were written to a computer file, which was then imported into a geographic information system (GIS) to convert the particle-tracking output data into a GIS polygon coverage that corresponded to 1- and 5-year CRA's.

A map of the 1- and 5-year CRA's is shown in figure 6 . This figure can be compared directly to Schalk's figure 9 (1996, p. 15). The configurations of the CRA's are almost identical to those of Schalk (1996). The primary differences between the two model results are that the refined grid spacing and increased number of particles in the revised model computes CRA's that have better resolution and have smoother boundaries. It is important to note that, for this simulation, the quarry of interest was not part of the simulation and was outside the 5-year CRA of all wells.

Particle tracking was also used to investigate potential changes in proportions of source waters for the wells. Particles were placed in each pumping well cell and tracked to the point of origin within the respective CRA. Results were compared for betweensimulation comparisons.

\section{Simulation 2-Quarry with 20-foot layer of undisturbed aquifer material}

Simulation 2, with the 20 -ft layer of undisturbed aquifer material left intact, was designed to represent current (1999) conditions within the study area. Pumping from the four collector wells and two conventional supply wells (FR-301 and FR-302) was set at a combined rate of $24.7 \mathrm{Mgal} / \mathrm{d}$. Simulation 2 (and all subsequent simulations) differ from simulation 1 , the revised model, because quarries were simulated as high-transmissivity zones instead of general-head boundaries.

Volumetric fluxes. Comparison of simulation 1 and 2 shows that the greatest differences in volumetric fluxes are for drains and river leakage. As a percentage of the total flux, however, flux to drains was insignificant. River leakage into the aquifer was greater in simulation 2 by about 10 percent. The greater river leakage is likely due to the removal of the head-dependent boundaries, which provided about $113,000 \mathrm{ft}^{3} / \mathrm{d}$ of water to the model. Withdrawal of water through wells was greater in simulation 2 (for a total of $24.7 \mathrm{Mgal} / \mathrm{d}$ ) as a result of including FR-301 and FR-302 (fig. 1). The amount of recharge was lower because recharge was rejected at dry cells in layer 1 where pumping of the two conventional supply wells caused drawdown of the water table into layer 2 . Volumetric fluxes for all model simulations are shown in table 2, and bar graphs of selected fluxes are shown in figure 7.

Particle tracking. Particle-tracking results for quarry operations with the 20 -ft layer of undisturbed aquifer material left in place are shown in figure 8. In general, the configurations of the CRA's closely match those of the simulation 1 , but two differences are notable. The first difference is in the 5-year CRA for

CW-115, and the second is in the northern part where the conventional supply wells FR-301 and FR-302 withdraw approximately $1 \mathrm{Mgal} / \mathrm{d}$ each. The 5-year CRA of CW-115 is greatly extended to the southeast as a result of the way the quarries are simulated. The pumping at wells FR-301 and FR-302 creates a flow divide within the area previously occupied by the 5-year CRA for CW-101, causing water flowing to CW-101 to be drawn in from other locations of the study area. The 5-year CRA for CW-101 extends further west and further northwest, with an arm extending along a tributary to the Scioto River caused by the pumping at the two conventional wells. The influence of pumping at these two wells is also evident as drawdown resulting in dry cells: two cells in the uppermost layer of the model are dry at well FR-302, and one cell in layer 1 is dry at well FR-301. Additionally, the 

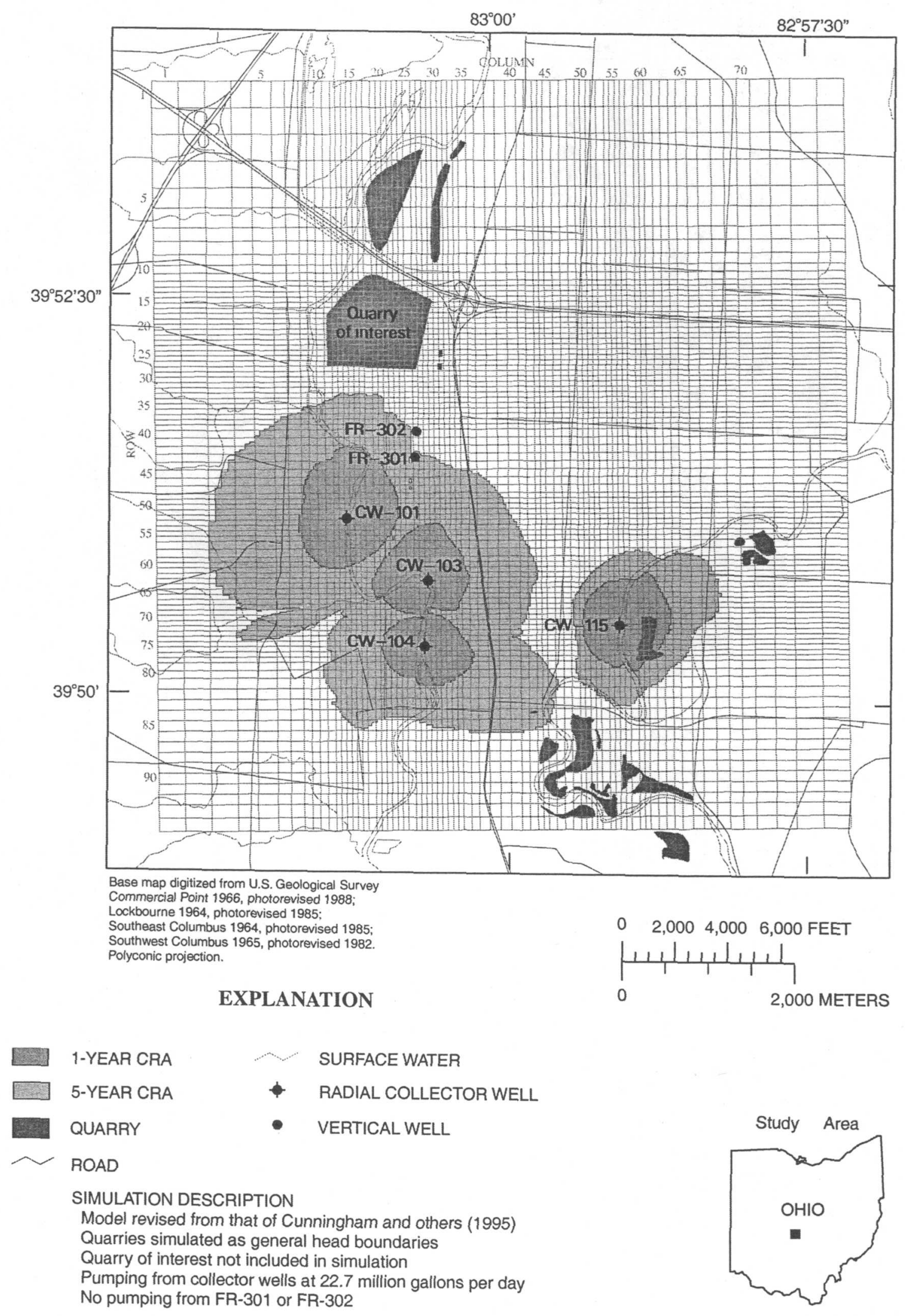

Figure 6. Contributing recharge areas (CRA's) for the revised ground-water flow model, southern Franklin County, Ohio. 

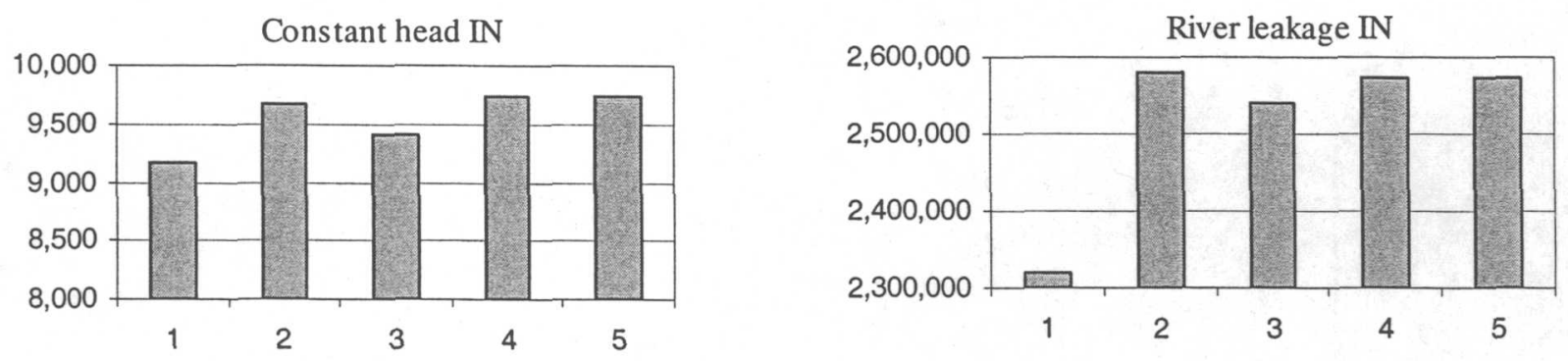

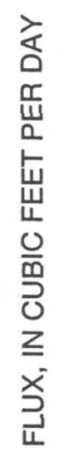
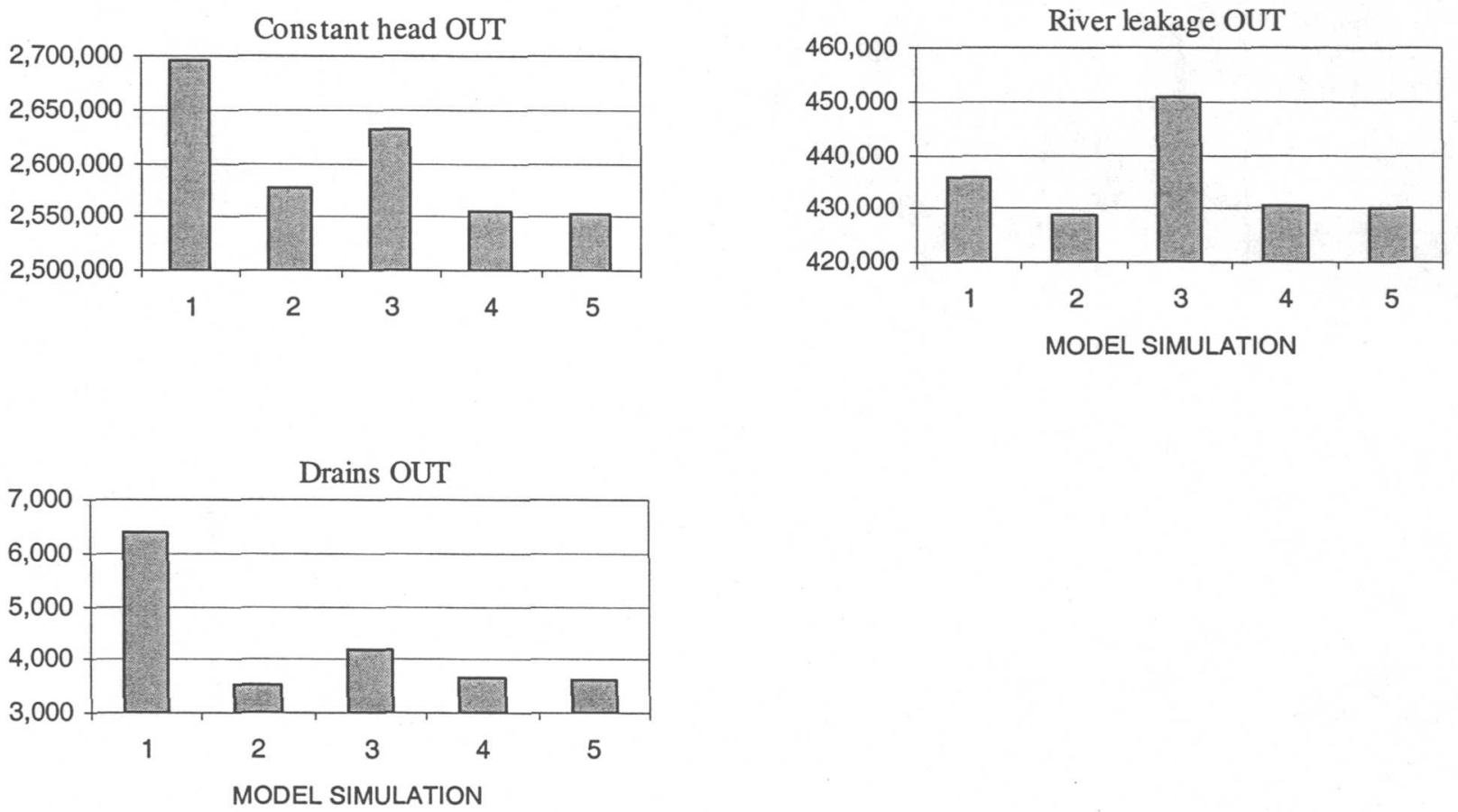

\section{EXPLANATION}

MODEL SIMULATION

1 Revised from that of Cunningham and others (1995); quarries simulated as general-head boundaries; pumping set at 22.7 million gallons per day

2 Simulation of quarries as high-transmissivity zones; 20-foot layer of undisturbed aquifer material left in; pumping set $\mathbf{2 4 . 7}$ million gallons per day

3 Removed 20 -foot layer of undisturbed aquifer material beneath quarry of interest

4 Silt in layers 1 and 2 (20-foot layer of undisturbed aquifer material left in)

5 Silt in layers 1,2 , and 3 (20-foot layer of undisturbed aquifer material replaced with silt)

Figure 7. Selected volumetric fluxes for five ground-water flow simulations, southern Franklin County, Ohio. 
Table 2. Volumetric fluxes from five ground-water flow model simulations, southern Franklin County, Ohio

[All values are in cubic feet per day; IN, volume of water exchanged from source or sink into the aquifer; OUT, volume of water exchanged from source or sink out of the aquifer]

\begin{tabular}{|c|c|c|c|c|c|c|c|c|c|c|}
\hline \multirow{2}{*}{ Source or sink of water } & \multicolumn{2}{|c|}{ Model simulation 1} & \multicolumn{2}{|c|}{ Model simulation 2} & \multicolumn{2}{|c|}{ Model simulation 3} & \multicolumn{2}{|c|}{ Model simulation 4} & \multicolumn{2}{|c|}{ Model simulation 5} \\
\hline & IN & OUT & IN & OUT & IN & OUT & IN & OUT & IN & OUT \\
\hline Constant head & 9,159 & $2,695,000$ & 9,679 & $2,576,300$ & 9,414 & $2,632,700$ & 9,737 & $2,555,300$ & 9,740 & $2,552,400$ \\
\hline Wells & $2,192,100$ & $3,043,000$ & $2,192,100$ & $3,305,400$ & $2,192,100$ & $3,305,400$ & $2,192,100$ & $3,305,400$ & $2,192,100$ & $3,305,400$ \\
\hline Drains & 0 & 6,388 & 0 & 3,533 & 0 & 4,189 & 0 & 3,645 & 0 & 3,625 \\
\hline Recharge & $1,500,200$ & 0 & $1,499,800$ & 0 & $1,499,900$ & 0 & $1,499,900$ & 0 & $1,499,900$ & 0 \\
\hline River leakage & $2,320,300$ & 435,730 & $2,580,400$ & 428,950 & $2,540,600$ & 450,760 & $2,575,000$ & 430,510 & $2,572,600$ & 429,950 \\
\hline Head-dependent boundary & 513,710 & 400,780 & 0 & -0 & 0 & 0 & 0 & 0 & 0 & 0 \\
\hline Total & $6,535,469$ & $6,580,898$ & $6,281,979$ & $6,314,183$ & $6,242,014$ & $6,393,049$ & $6,276,737$ & $6,294,855$ & $6,274,340$ & $6,291,375$ \\
\hline
\end{tabular}

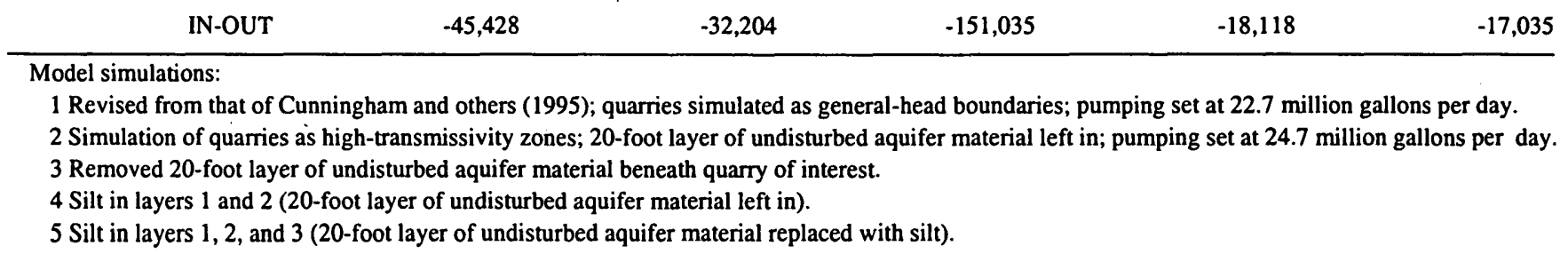

northernmost extent of the 5-year CRA from well FR-302 makes contact with the southern boundary of the quarry of interest. This contact indicates that at least part of the water withdrawn through well FR-302 is contributed by water that once resided within the quarry.

\section{Simulation 3-Quarry with removal of 20-foot layer of undisturbed aquifer material}

Simulation 3, without the $20-\mathrm{ft}$ layer of undisturbed aquifer material, was designed to represent conditions within the study area in the event that the mining company removes all sand and gravel down to the limestone bedrock. The sand and gravel in layer 3 within the quarry of interest were replaced with a high-transmissivity zone, and porosity was set to 100 percent. Pumping from the four collector wells and two conventional supply wells remained at a combined rate $24.7 \mathrm{Mgal} / \mathrm{d}$. No other changes were made to the model.

Volumetric fluxes. Volumetric budgets of simulations 2 and 3 are nearly identical. The slight dif- ferences in constant-head, drains, and river-leakage fluxes constitute less than 1 percent of the total water budget of the model. Removal of the $20-\mathrm{ft}$ layer of undisturbed aquifer material results in more water lost to the limestone quarry to the north, which was simulated as a constant-head boundary. Additionally, river leakage into the aquifer decreased by about 1.5 percent, whereas river leakage out of the aquifer and into the river increased by about 5 percent. This is likely the result of the encroachment of the 5-year CRA of FR-302 to the quarry of interest.

Particle tracking. Particle-tracking results for model simulation 3 are shown in figure 9 . The results for simulations 2 and 3 are almost identical, with changes noted only in individual cells along the periphery of the CRA's. The CRA's to wells FR-301 and FR-302 do not extend as far west as for simulation 2. One cell in layer 1 went dry at well FR302 , and one cell in layer 1 went dry at FR-301, an indication that drawdown for this simulation is slightly less than that of simulation 2 . 


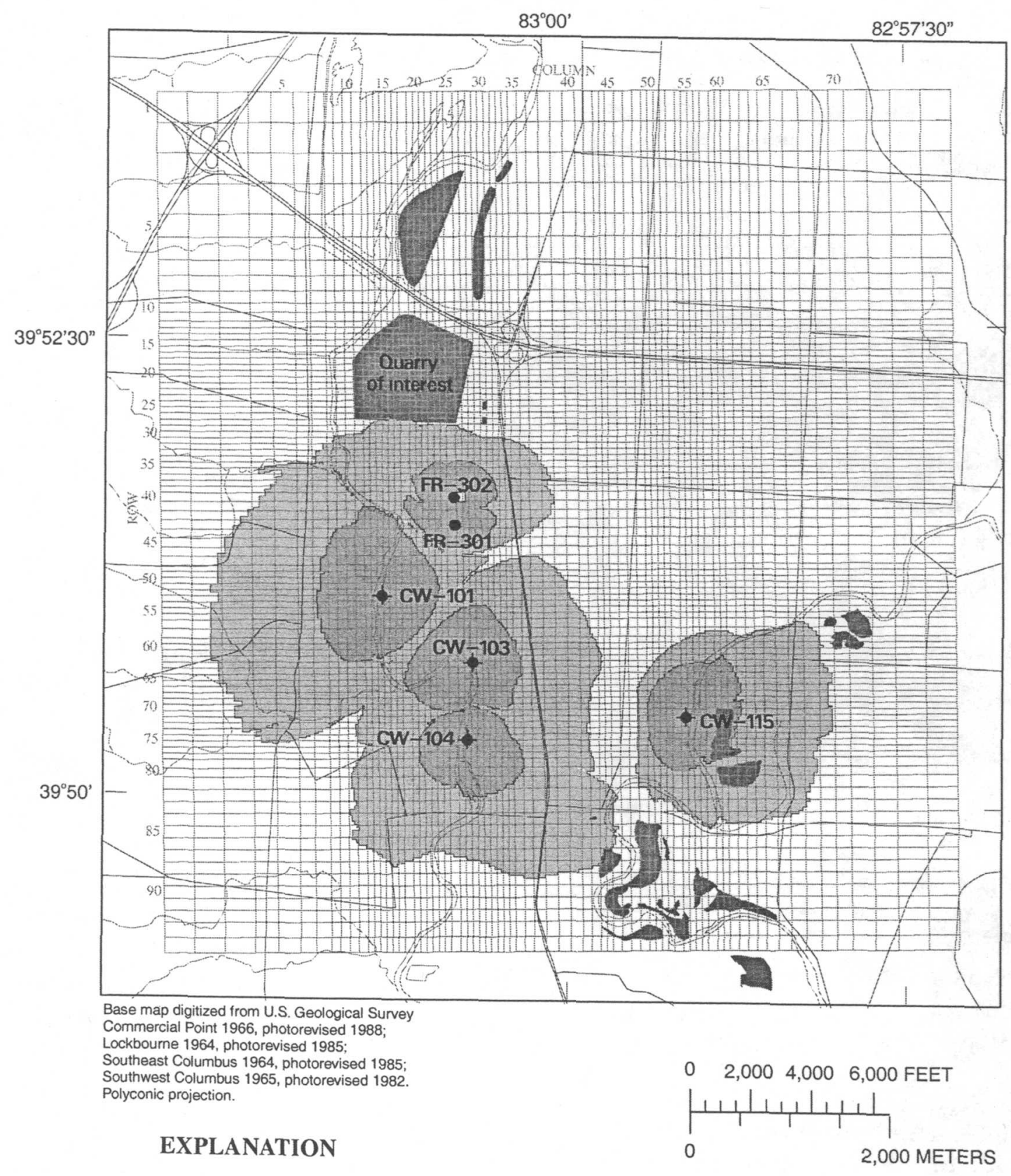

1-YEAR CRA

SURFACE WATER

5-YEAR CRA

QUARRY

RADIAL COLLECTOR WELL

- VERTICAL WeLL

ROAD

SIMULATION DESCRIPTION

Quarries simulated as high-transmissivity zones

Quarry of interest included in simulation

Pumping from collector wells at 22.7 million gallons per day

Pumping from FR-301 and FR-302 at 1 million gallons per day each

20-foot layer of undisturbed aquifer material left intact

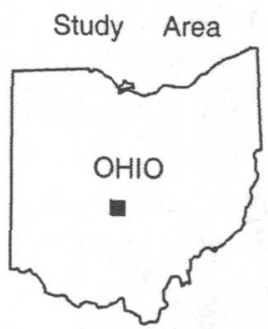

Figure 8. Contributing recharge areas (CRA's) for simulation 2, southern Franklin County, Ohio. 


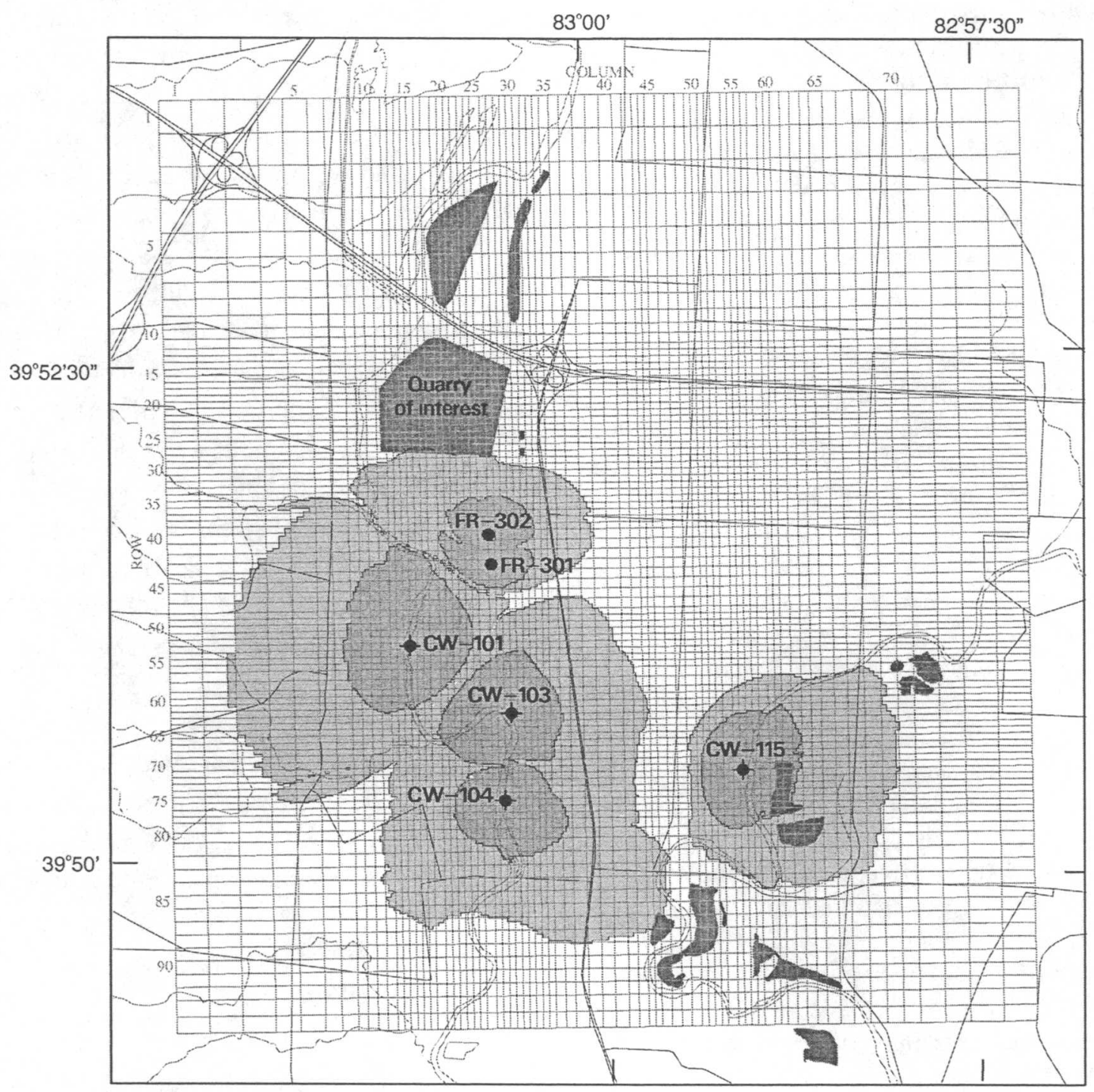

Base map digitized from U.S. Geological Survey Commercial Point 1966, photorevised 1988

Lockbourne 1964, photorevised 1985;

Southeast Columbus 1964, photorevised 1985:

Southwest Columbus 1965, photorevised 1982

Polyconic projection.

\section{EXPLANATION}

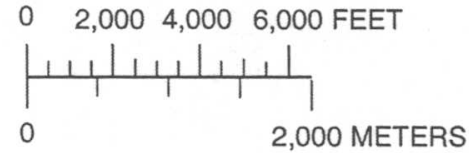

1-YEAR CRA

5-YEAR CRA

QUARRY

\author{
SURFACE WATER \\ - RAdial collector well \\ - Vertical Well
}

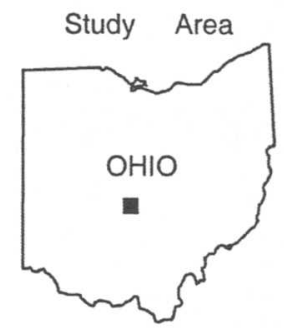

Figure 9. Contributing recharge areas (CRA's) for simulation 3, southern Franklin County, Ohio. 
Simulation 4 -Quarry filled with lowtransmissivity aquifer material over 20-foot layer of undisturbed aquifer material

Simulation 4 represents backfilling of the quarry of interest with the fine-grained sand and silt that are the byproducts of sand and gravel mining. The finegrained sand and silt were represented by placing a zone of low-transmissivity materials within the quarry. Transmissivity was decreased by 2 orders of magnitude, and porosity of the silt was assigned a value of 20 percent. Simulation 4 is based on the assumption that only layers 1 and 2 will be mined and backfilled with fine-grained sand and silt.

Volumetric fluxes. The volumetric fluxes for simulation 4 (table 2) differ little from those in simulations 2 and 3 . In simulation 4 , the replacement of layers 1 and 2 with fine-grained sand and silt results in more water being contributed to the aquifer by constant-head cells. The total volume of water derived from constant-head cells in simulation 4 increased by about 3.5 percent over the amount derived in simulation 3 and increased over simulation 2 by less than 1 percent. These increases, however, are both less than 1 percent of the total water budget of the model. In simulation 4 , approximately $34,000 \mathrm{ft}^{3} / \mathrm{d}$ more water entered the aquifer from the river than for simulation 3 and $5,400 \mathrm{ft}^{3} / \mathrm{d}$ less than simulation 2 . This was likely due to the decrease in amount of water available from upgradient sources, where the low hydraulic conductivity inhibits the flow of water. This, in turn, causes more water to be drawn from the rivers.

Particle tracking. Particle tracking to pumped wells was used on simulation 4 to determine whether backfilling of the quarry of interest significantly affects the size and (or) shape of the 1- and 5-year CRA's. The configuration of the CRA boundaries for simulation 4 is shown in figure 10. Siltation of layers 1 and 2 results in changes to the northern edge of the CRA's to wells FR-301 and FR-302. Because porosity of the infilled materials also was decreased, the CRA extends farther into the quarry.

\section{Simulation 5-Quarry filled with low- transmissivity aquifer material with the 20-foot layer of undisturbed aquifer material removed}

Simulation 5 represents backfilling of the quarry of interest with the fine-grained sand and silt that are the byproduct of sand and gravel mining. The fine-grained sand and silt were represented by placing a zone of low-transmissivity materials within the quarry. Transmissivity was decreased by 2 orders of magnitude, and porosity of the silt was assigned a value of 20 percent. Simulation 5 is based on the assumption that the entire thickness of sand and gravel (layers 1, 2, and 3) was mined out of the quarry of interest and was replaced with fine-grained sand and silt.

Volumetric fluxes. Results for simulation 5 indicate that the volumetric fluxes for this simulation are almost identical to those of simulation 4 . In simulation 5 , however, there is a slight decrease $\left(2,400 \mathrm{ft}^{3} / \mathrm{d}\right)$ in the amount of water that enters the aquifer through river leakage as compared with simulation 4; this difference is less than 1 percent of the water budget for the model. This decrease probably results from the placement of silt in layer 3 , which slightly reduces the amount of water that wells FR-301 and FR-302 can obtain from the river to the west and southwest of quarry of interest.

Particle tracking. For simulation 5, slight changes result along the northern extent of the CRA boundaries within the quarry. Comparison of simulation 5 to simulation 4 shows that fewer cells of the 5-year CRA for FR-302 are within the quarry for simulation 5. There are no significant effects on any of the CRA's for the collector wells.

\section{Simulated effects of quarrying operations on proportion of source waters for wells}

The sources of water to the four radial-collector wells and the two conventional wells include groundwater inflow, streamwater infiltration, bedrock, recharge to the water table, and (or) flow through quarries. Because each of these potential sources has unique water-quality characteristics, it is important to define how much water is contributed by each source. The sources of water for the supply wells was determined by placing approximately 1,000 hypothetical particles of water in each grid cell containing a well. The particles were equally spaced along a vertical line within the screened interval and were backtracked to their point of origin within the 5-year CRA using the program MODPATH (Pollock, 1994). The number of particles that ended in a given zone were weighted by 


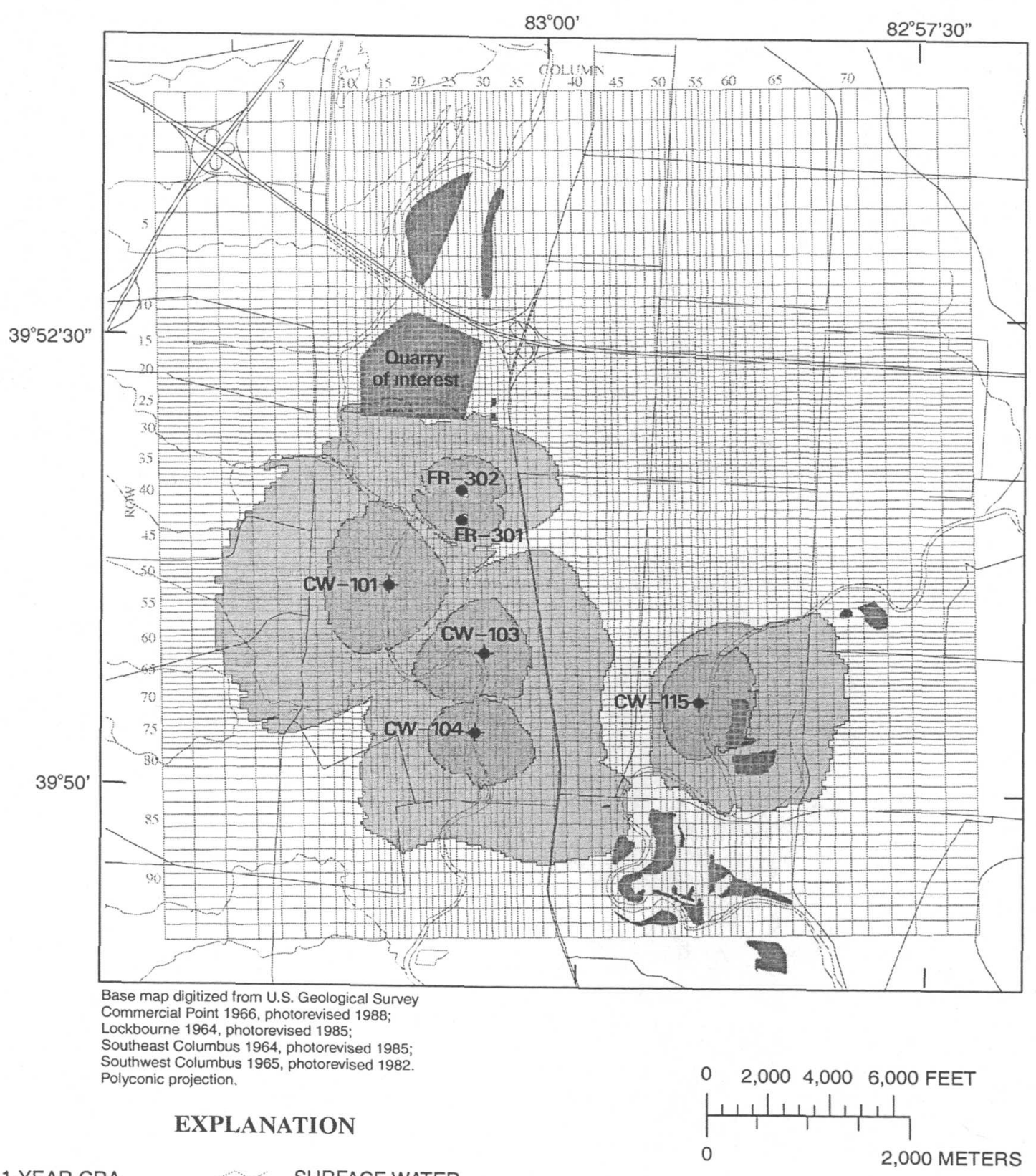
1-YEAR CRA
SURFACE WATER
5-YEAR CRA
- radial collector well

QUARRY

- vertical well

ROAD

SIMULATION DESCRIPTION

Quarries simulated as high-transmissivity zones

Quarry of interest included in simulation

Pumping from collector wells at 22.7 million gallons per day

Pumping from FR-301 and FR-302 at 1 million gallons per day each

20-foot layer of undisturbed aquifer material left in at quarry of interest

Layers 1 and 2 at quarry of interest replaced with low-transmissivity silt

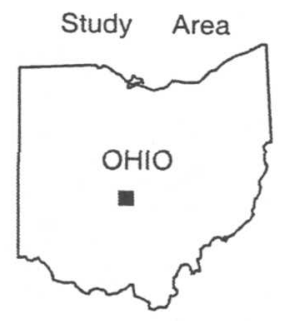

Figure 10. Contributing recharge areas (CRA's) for simulation 4, southern Franklin County, Ohio. 


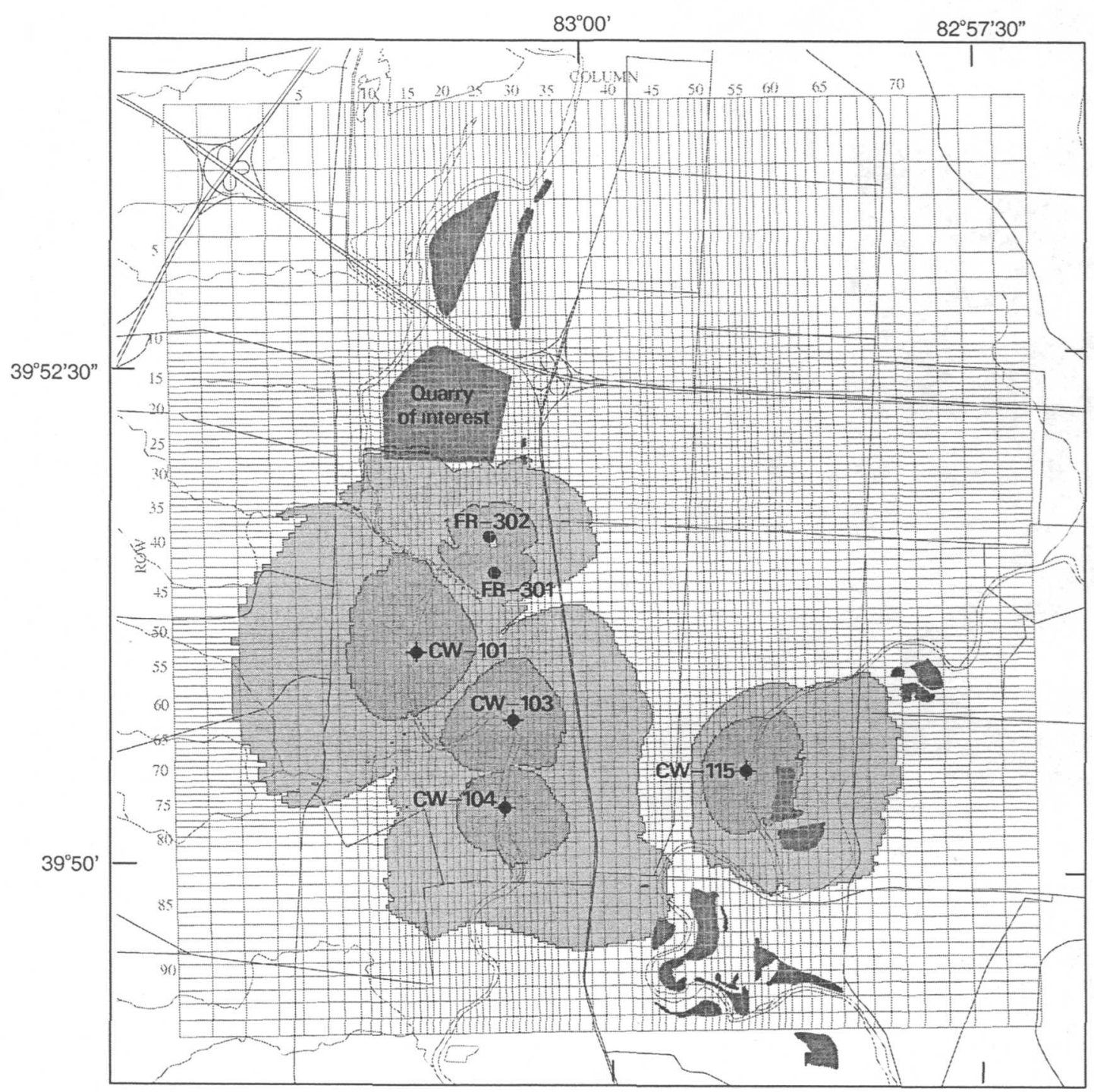

Base map digitized from U.S. Geological Survey Commercial Point 1966, photorevised 1988;

Lockbourne 1964, photorevised 1985;

Southeast Columbus 1964, photorevised 1985:

Southwest Columbus 1965, photorevised 1982 Polyconic projection.

\section{EXPLANATION}

1-YEAR CRA

5-YEAR CRA

QUARRY

\section{ROAD}

SIMULATION DESCRIPTION

Quarries simulated as high-transmissivity zones

Quarry of interest included in simulation

Pumping from collector wells at 22.7 million gallons per day

Pumping from FR-301 and FR-302 at 1 million gallons per day each

Layers 1, 2, and 3 (20-foot layer of undisturbed aquifer) replaced with low-transmissivity silt at quarry of interest
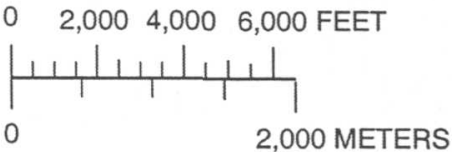
the pumping volume of their source well and were compiled for each model simulation. MODPATH cannot accurately determine the amount of water from each source using this method because water may not enter a well screen in equal amounts throughout its screened interval; however, each well was dealt with in an identical manner, and the results are considered to be suitable for semiquantitative comparisons among results of the five simulations.

The primary sources of water examined in this study were the Scioto River, Big Walnut Creek, the quarry of interest, all other quarries (combined), and bedrock. During MODPATH computations, particle pathlines were backtracked to a specified zone or stopped after 5 years of traveltime. If particle pathlines ended within the aquifer or on the water table, they would not be allocated to a specified zone. Thus, the tally of particles at the end of the simulation might be less than the total number of particles released. Alternatively, the tally of particles could equal more than the total number of particles released because the particle pathlines may traverse more than one zone. Of importance in this analysis is not only the source of water to supply wells but also the hydrochemical environment along the flowpath, because particles that travel through a given zone may take on the chemical characteristics of that zone. If, for example, a particle of water originated as recharge on the water table, traveled through sand and gravel and entered bedrock, and then moved through a quarry, the source zones would include bedrock and the quarry. Because the chemical quality of water in bedrock from this area is poor, the influence of bedrock-water-quality characteristics is important in assessing the effects of quarrying operations on the composite water quality at the supply wells.

The percentage of particles from each zone for each of the five model simulations for the study area is given in table 3 and figure 12. Between simulation 1 and all other simulations, the most significant differences are seen in the number of particles gained or lost from Big Walnut Creek and the other quarries. This is likely the result of changes to the way quarries were simulated (from general-head boundaries to hightransmissivity zones). As much as 2 percent of the total particles withdrawn through wells (mostly through FR-302) travel through or originate in the quarry of interest in model simulation 3 , where the quarrying operations are active and the 20 -ft layer of undisturbed aquifer material is removed. When the quarry is filled in with low-transmissivity materials, less than 1 percent of the particles originate or pass through the quarry of interest.

Table 3. Percentage of water derived from different sources for five ground-water flow simulations, southern Franklin County, Ohio

\begin{tabular}{cccccc}
\hline $\begin{array}{c}\text { Model } \\
\text { simulation }\end{array}$ & $\begin{array}{c}\text { Scioto } \\
\text { River }\end{array}$ & $\begin{array}{c}\text { Big } \\
\text { Walnut } \\
\text { Creek }\end{array}$ & $\begin{array}{c}\text { Quarry } \\
\text { of interest }\end{array}$ & $\begin{array}{c}\text { Others } \\
\text { quarries }\end{array}$ & Bedrock \\
\hline 1 & 33 & 16 & 0 & 8 & 27 \\
2 & 32 & 21 & 1 & 12 & 28 \\
3 & 33 & 20 & 2 & 12 & 27 \\
4 & 32 & 21 & $<1$ & 12 & 28 \\
5 & 32 & 21 & $<1$ & 12 & 28 \\
\hline
\end{tabular}

\section{Summary and conclusions}

The municipal well field operated by the City of Columbus is near a sand and gravel mining operation that plans to remove part of the material that constitutes the aquifer in the well field. Mining of the aquifer in this area has the potential to change the sources of water to supply wells, which might include infiltration from rivers, bedrock, and flow through existing quarries. Five different model simulations and particletracking analysis were done to evaluate the influence of various current (1999) and near-future mining scenarios on the size and shape of contributing recharge areas to wells. The main differences between the revised model used for these simulations and two previously published models were (1) another model layer was added to simulate a 20 -ft layer above bedrock, (2) the model grid was rediscretized to a finer grid spacing, (3) quarries were simulated as hightransmissivity zones as opposed to general-head boundaries, and (4) pumpage was increased from 22.7 to $24.7 \mathrm{Mgal} / \mathrm{d}$.

The revised model was adjusted to fit heads and flows of an earlier steady-state simulation. Resultant heads were slightly lower in the revised model because of river-cell and vertical-conductance changes made during model fitting. Volumetric fluxes for the revised model were within 2 percent of previously published models. The revised model-computed heads were most sensitive to decreases in riverbed conductance. The computed heads were also moderately 


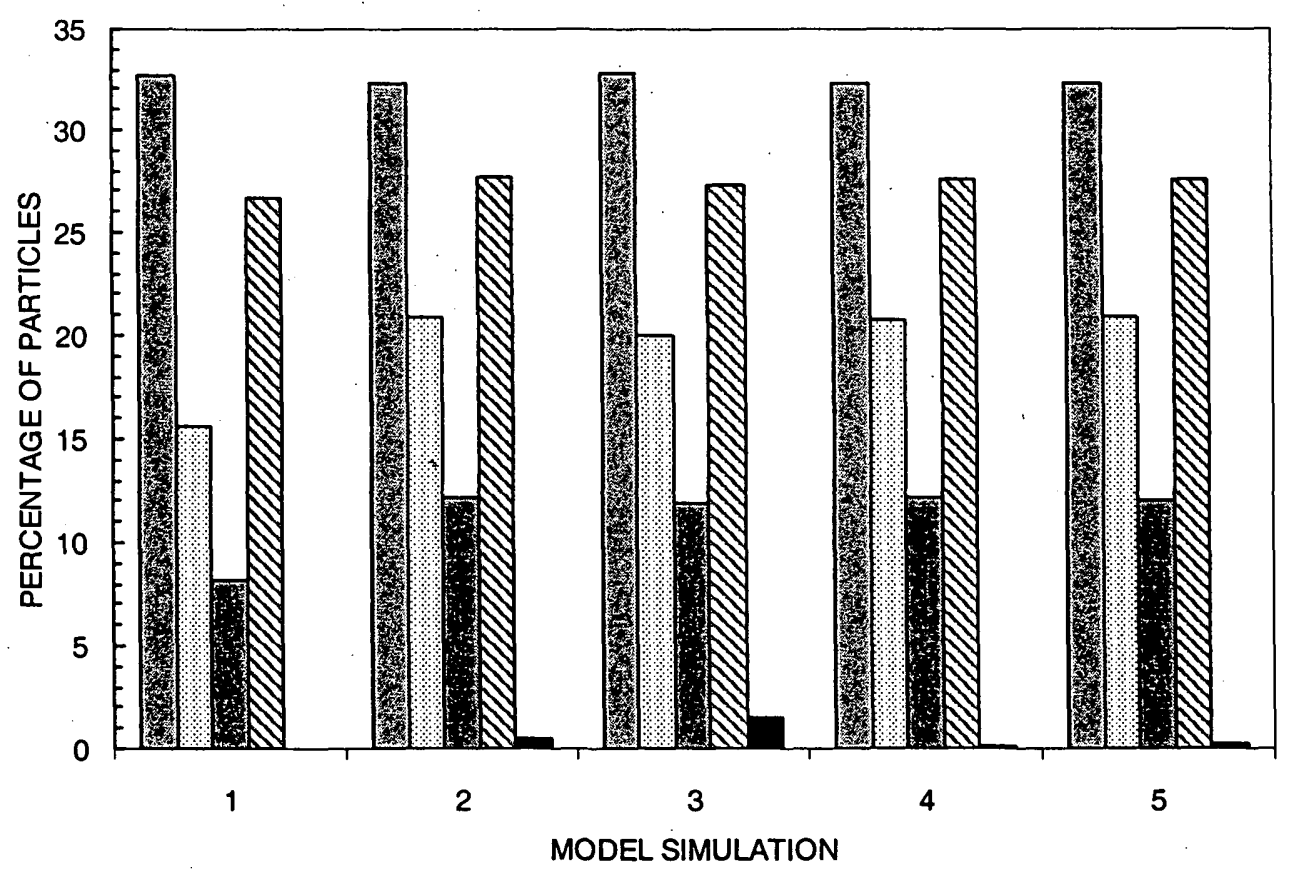

EXPLANATION

SCIOTO RNER
BIG WALNUT CRETK
MODEL SIMULATION
1 Revised from that of cunningham and others (1995); quarries simulated as general-head
boundaries; pumping set at 22.7 million gallons per day. Quarry of interest not included
in this simulation
2 Simulation of quarries as high-transmissivity zones; 20 -foot layer of undisturbed aquifer
material left in; pumping set 24.7 million galions per day
3 Removed 20-foot layer of undisturbed aquifer material beneath quarry of interest
4 Silt in layers 1 and 2 (20-foot layer of undisturbed aquifer material left in)
5 Silt in layers 1, 2, 3 (20-foot layer of undisturbed aquifer material replaced with silt)

Figure 12. Proportions of source waters for pumped wells from five ground-water flow simulations, southern Franklin County, Ohio.

sensitive to changes in hydraulic conductivity of layers 1,2 , and 3, and to recharge.

Additional model simulations investigated the effects of leaving a 20 - $\mathrm{ft}$ layer of undisturbed aquifer material within the quarry of interest above bedrock. It was anticipated that this layer would serve as a barrier to increased flow of water of poor quality from bedrock. Other simulations examined the influence of removing the $20-\mathrm{ft}$ layer and then filling the quarry with fine-grained sand and silt, which is a byproduct of sand and gravel processing.

The results of model simulations indicate that the volumetric budgets between models differ only slightly in response to various conditions at the quarry.
The amount of water that the aquifers gained from constant-head boundaries and river leakage increased primarily because of the way the quarries were simulated and the overall lower heads in the aquifers than in earlier simulations. The size and shape of the contributing recharge areas (CRA's) differed as a result of the greater withdrawals from two additional conventional supply wells. Previously published model simulations showed that the 5-year CRA did not intersect with the quarry of interest on the north side of the study area. With the inclusion of two additional conventional supply wells in the revised model simulation, however, the computed 5-year CRA from one of the vertical wells intersects the quarry. 
Because water quality is different from each of the sources of water identified in the model, particletracking analysis was used to learn about how quarrying operations might affect the sources of water to supply wells. The number of particles derived from the rivers, other quarries (excluding the quarry of interest), and bedrock stayed relatively constant throughout the model simulations. The number of particles that originated in the quarry of interest increased from about 1 percent of the total particles when the $20-\mathrm{ft}$ layer of undisturbed aquifer material was left intact to 2 percent when the layer was removed. When the quarry was backfilled with fine-grained sand and silt, the percentage of particles that travel through or originate in the quarry decreased to less than 1 percent of the total number of particles.

Close examination of the configuration of the computed CRA's for all five models shows that, between each model run, the boundaries may shift by one or two cells. Even when the only changes in the model are made near the quarry of interest, there may still be small changes in the configuration of the computed 5-year CRA's several miles from the area of model modifications (compare the eastern boundary of the 5-year CRA for CW-115 for models 2, 3, and 4, in figures 8,9 , and 10 ). Therefore, when defining the edge of a CRA, it would be more appropriate to draw a thick, dashed line (at least one half the width of the grid cell) because the edge actually lies within a zone of uncertainty.

\section{References cited}

Bair, E.S., Sheets, R.A., and Eberts, S.M., 1990, Particle tracking as a method to determine flow paths and traveltimes from hypothetical spill sites within the capture zone of a municipal well field: Ground Water, v. 28, no. 6, p. 884-892.

Cunningham, W.L., Bair, E.S., and Yost, W.P., 1995, Hydrogeology and simulation of ground-water flow at the South Well Field, Columbus, Ohio: U.S. Geological Survey Water-Resources Investigations Report 95$4279,56 \mathrm{p}$.

de Roche, J.T., 1985, Hydrogeology and effects of landfills on ground-water quality, southern Franklin County, Ohio: U.S. Geological Survey Water-Resources Investigations Report 85-4222, 58 p.

de Roche, J.T., and Razem, A.C., 1984, Water quality of a stream-aquifer system, southern Franklin County, Ohio: U.S. Geological Survey Water-Resources Investigations Report 84-4238, 44 p.
Eberts, S.M., and Bair, E.S., 1990, Simulated effects of quarry dewatering near a municipal well field: Ground Water, v. 28, no. 1, p. 37-47.

McDonald, M.G., and Harbaugh, A.W., 1988, A modular three-dimensional finite-difference ground-water flow model: U.S. Geological Survey Techniques of WaterResources Investigations, book 6, chap. A1, $586 \mathrm{p}$.

Pollock, D.W., 1994, User's guide to MODPATH/MODPATH-PLOT, version 3, a particle tracking post-processing package for MODFLOW, the U.S. Geological Survey finite-difference ground-water flow model: U.S. Geological Survey Open-File Report 94-464 [variously paginated].

Schalk, C.W., 1996, Estimation of the recharge areas contributing water to the South Well Field, Columbus, Ohio: U.S. Geological Survey Water-Resources Investigations Report 96-4039, 26 p. 


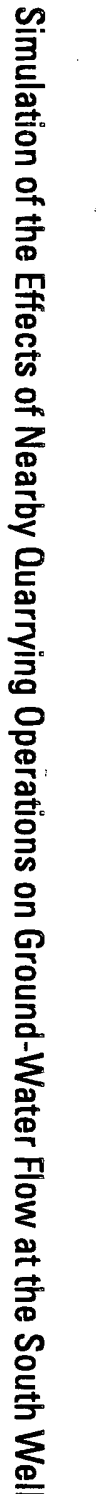

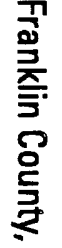

음.

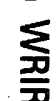

